\title{
Market knowledge: Evidence from importers
}

\author{
Aksel Erbahar ${ }^{1,2}$ \\ ${ }^{1}$ Erasmus School of Economics (ESE), Erasmus University Rotterdam, Rotterdam, The Netherlands \\ ${ }^{2}$ Tinbergen Institute, Rotterdam, The Netherlands
}

\section{K E Y W O R D S}

export diversification, learning by importing, market entry, networks

\section{1 | INTRODUCTION}

Exports play a crucial role in firms' growth. The most productive firms select into exporting and end up serving multiple destinations, being able to cover the sunk costs of entry for each market. This diversification of export markets not only contributes to the growth of the firm but also hedges the risks of relying on a single export market. Thus, many countries have policies that promote exports and export-market diversification via subsidies for market research and international trade fairs. The seminal paper by Roberts and Tybout (1997) established that there are substantial costs of entry into new markets. ${ }^{1}$ Theoretical works by Melitz (2003), Helpman, Melitz, and Rubinstein (2008), Chaney (2008), and Eaton, Kortum, and Kramarz (2011) incorporated the extensive margin of trade into heterogeneous firms models by including a fixed cost of exporting. Importantly, to explain the consumer extensive margin of trade, Arkolakis (2010) formalised a model that endogenises the entry cost by incorporating destination-specific marketing costs. $^{2}$

The black box of entry costs created a literature on networks and how they can reduce trade frictions by spreading information. Chaney (2014) built a model where firms acquire new customers through their networks in existing export markets and thus enter into markets that are geographically closer to their existing destinations. ${ }^{3}$ The model predicts that firms can search for clients remotely using their existing clients. Following his conjecture, this paper examines whether firms use their existing suppliers in a destination to find their first clients in those markets based

\footnotetext{
${ }^{1}$ Other papers that find these costs include Bernard and Jensen (2004) for US firms, Das, Roberts, and Tybout (2007) for Colombian firms and Özler, Taymaz, and Yilmaz (2009) for Turkish firms. Kasahara and Rodrigue (2008), on the other hand, find sunk costs for importing.

${ }^{2}$ From an empirical viewpoint, Gullstrand (2011) examined Swedish food exporters and found that export costs are firm-destination-specific. Similarly, Moxnes (2010) discovered that market-specific costs are about three times as large as global exporting costs using Norwegian firm-level data.

${ }^{3}$ This "extended-gravity" pattern of export expansion is formally described in a gravity setting and structurally estimated by Morales, Sheu, and Zahler (2014).
}

This is an open access article under the terms of the Creative Commons Attribution License, which permits use, distribution and reproduction in any medium, provided the original work is properly cited.

(C) 2018 The Authors. The World Economy Published by John Wiley \& Sons Ltd 
on an "extended-Chaney" information channel. Taken to the data, the question I explore in this paper is as follows: Does a firm's previous experience importing from a country increase its probability to start exporting to that country?

I empirically test whether the probability of entering an export-market depends on a firm's previous import experience with that country using a highly disaggregated data set on Turkish manufacturing firms' export and import statistics at the product-country level for the 2003-08 period. Turkey, a globally integrated large developing economy, is a suitable setting for this analysis as Turkey's dollar value of exports increased by 183 per cent from 2003 to 2008, and 22 per cent of this is explained by exporters adding new destinations to their portfolios. ${ }^{4}$

The paper's main specification aims to capture the effect of import experience on a firm's subsequent export entry to that market. Since there might be many factors that affect a firm's market entry, I use multiple high-dimensional fixed effects including firm-year dummies to control for inherent and time-varying productivity, and country-industry-year dummies to control for variables such as supply/demand functions and trade costs. In order to address potential endogeneity concerns, I employ an instrumental variables (IV) strategy where the instrument for import experience is the country-specific export supply of the basket of goods that a firm has imported in the past. Results show that having an existing supplier in the destination country raises the probability of export-market entry by 5.5 percentage points on average (11 percentage points in the main IV specification) - a large number when compared to the mean export-market entry probability of 0.8 per cent. My sensitivity analyses using different samples, experience measures and multiple instruments support the findings and establish that importing from a country increases the likelihood of export-market entry, revealing a "market knowledge" phenomenon.

The detailed data enable me to dig deeper. First, I take advantage of country characteristics and use gravity-type variables such as GDP, distance, language proximity and regional trade agreements (RTAs). Results show that the effect of having a supplier in the destination country does not exist when trading with low-income countries, but it is greater for larger and more proximate countries. In addition, language proximity increases the size of the effect, whereas having an RTA with the destination country decreases it. Moreover, I find that the size of a firm's domestic network, measured by the number of same-industry firms in Turkey that already export to the destination, has an additional positive effect on export-market entry. Similarly, the size of the Turkish immigrant community in the destination country increases the probability of entering that market, even when the firm has a supplier in that country. Second, I analyse whether the firm and product characteristics that proxy the strength of the firm's relationship with its supplier matter. Results indicate that the value of imports, the number of products imported, the share of country-specific imports in a firm's total imports, the share of imported products that are differentiated (both horizontally and vertically), the share of imports that are intermediates and the share of imports that are technology-intensive all have a positive and significant effect on the probability of starting to export.

This paper's main contribution to the literature is finding for the first time that firms' countryspecific import experience increases the probability of starting to export to that country. From a network analysis perspective, this finding is informative, as it reveals that firms can learn about new clients not only through their existing clients but also through their existing suppliers,

\footnotetext{
${ }^{4}$ The remaining is explained by the new exporter extensive margin (27\%) and the firm-destination intensive margin (51 per cent). Note that the Turkish lira appreciated about $14 \%$ over the dollar during this period and thus the growth in exports was 146 per cent in liras. See Cebeci and Fernandes (2015) for an in-depth look at the decomposition of Turkey's export boom in this period.
} 
indicating that the size of a firm's network can expand in both ways. Note that even though this paper indirectly tests for network formation using an import experience proxy, the results can be interpreted as a test for any type of market knowledge such as customs procedures, language and culture. However, analysing the results reveals that the "supplier network" hypothesis, where firms learn about potential clients, is more important than the alternative explanation that emphasises the shared fixed cost component of exporting to or importing from a country. The policy implications of my results give credit to governments' export promotion programmes such as trade fairs that aim to help firms find the first contact. Moreover, results indicate that large-scale trade policy implementations such as unilateral tariff liberalisation can have additional spillover effects by allowing firms to find suppliers in new markets that can eventually lead to finding new clients in those markets.

My empirical results are related to three strands of the heterogeneous firms and trade literature. First is the literature on the importance of information frictions in export-market entry as formalised by Chaney (2014) in a dynamic setting, which revealed the importance of geography in firms' export expansion patterns. Another related work is by Allen (2014), who quantified the importance of information frictions by examining agricultural trade data in the Philippines, and found that a significant portion of regional price dispersion was due to limited knowledge of prices elsewhere. Pioneered by the work of Rauch (1999), who showed that trading of differentiated products involve higher informational barriers, this literature focused largely on social and business networks in destination countries and their positive effect on trade: Rauch and Trindade (2002) found that bilateral trade in differentiated products is higher between countries that have larger ethnic Chinese population shares; Combes, Lafourcade, and Mayer (2005) examined regional trade within France and discovered that the size of migrant and plant networks increase trade flows of French firms; and Bastos and Silva (2012), using Portuguese firm-level data, found that the destination-specific size of emigrant networks increases firms' export participation and intensity. ${ }^{5}$ The novelty of this paper is to use import experience as a proxy of network linkages that are destination- and firm-specific.

The second strand of the literature that this paper relates to is the firm-level research on learning. Schmeiser (2012), using Russian firm-level data, found that market-entry costs depend on a firm's previous experience with similar export markets, and called this "learning to export." Similarly, Defever, Heid, and Larch (2014) used Chinese firm-level data and discovered that the elimination of the Multi Fibre Arrangement (MFA) caused Chinese firms to start exporting to nonMFA destinations that border MFA countries, concluding that export extensive margins have a spatial pattern. Koenig (2009), Cassey and Schmeiser (2013), and Fernandes and Tang (2014) examined learning through observing other exporters for France, Russia and China, respectively, and found important "peer effects." Similarly, Albornoz, Pardo, Corcos, and Ornelas (2012) and Eslava, Tybout, Jinkins, Krizan and Eaton (2014) analysed learning about market-specific demand for Argentinean and Colombian firms, respectively, and found that geographic expansion of a firm's exports depends on its previous export experience in other destinations. However, none of these papers explored the firm's previous experience with the same market as done in this paper.

Finally, this paper is indirectly related to the relationship between a firm's export and import activities. This is studied by Aristei, Castellani, and Franco (2013) who used firm-level survey data from 27 countries and found that a firm's importing increases its exports while a firm's exporting

\footnotetext{
${ }^{5}$ This literature is also tied to the "intermediation" of trade that emphasises breaking informational barriers, theoretically developed by Casella and Rauch (2002) and later by Ahn, Khandelwal, and Wei (2011) in a heterogeneous firms framework.
} 
does not have any effect on its imports. Turco and Maggioni (2013) did a similar analysis for Italian firms and found that importers are more likely to start exporting. Pierola, Fernandes, and Farole (2018) found that Peruvian firms that import intermediate inputs have better export performance, including greater export-market diversification. Muûls and Pisu (2009) found that export status is positively correlated with both previous export and import experience and vice versa, confirming that there are substantial sunk costs of entry. However, none of these papers have looked at whether a firm's likelihood to enter an export-market depends on that firm's previous import experience from that country. 6,7

The remainder of the paper proceeds as follows. Section 2 presents the theoretical motivation, sets up the main empirical specification and explains the identification strategy. Section 3 describes the data and presents summary statistics. In Section 4, I present the main results with robustness checks. In Section 5, I explore heterogeneous effects using country, firm and product characteristics, and also discuss the potential learning mechanisms behind the results. Finally, Section 6 concludes and discusses further research.

\section{2 | THEORY AND EMPIRICAL STRATEGY}

\section{1 | Theoretical motivation}

This paper is influenced by Chaney's (2014) theoretical setup, where firms search for clients by using their existing dynamically formed networks. Importantly, he assumes that firms can only sell to clients that they have met through a network. This assumption is micro-founded in a slightly modified Krugman (1980) model with informational asymmetries and moral hazard leading to each consumer having access to a different mass of goods and also each firm having access to a different mass of consumers. Each period, firms sample a mass of clients and successfully match with a proportion of them. ${ }^{8}$ The model also assumes that this costly search can be made from the firm's origin and also remotely through the location(s) of its existing client(s).

The number of customers firm $i$ has in time $t$ in location $x$ is $f_{i, t}(x)$. Firms search for consumers directly from where they are located (call it 0 ) and find $\widetilde{\gamma \mu}$ new clients, a positive-integer random variable with mean $\gamma \mu$, where $\gamma$ is the constant growth rate of firms in each location and $\mu$ is a positive parameter that describes the efficiency of search technology. In addition, firms search remotely through their existing contacts in other destinations (call it $y$ ) and find $\widetilde{\gamma \mu \pi}$ new clients, again a positive-integer random variable with mean $\gamma \mu \pi$, where $\pi$ is a non-negative parameter that

\footnotetext{
${ }^{6}$ The paper's policy implications are related to the export promotion literature that emphasises export diversification; see, for example, Lederman, Olarreaga, and Payton (2010), Martincus and Carballo (2008, 2010), and Martincus, Estevadeordal, Gallo, and Luna (2010).

${ }^{7}$ This paper is also influenced by ideas in the business economics literature. The importance of market knowledge per se is highlighted by Kneller and Pisu (2011) who used a detailed firm-level survey from the UK and found that the largest barrier to export is identifying the first contact and marketing costs. Pinho and Martins (2010), by analysing a sample of 1,200 Portuguese SME firms, found that the two main hindrances to exporting were (i) lack of knowledge of potential markets, and (ii) lack of qualified export personnel. They found that lack of technical suitability, degree of competition in the sector, lack of financial assistance and lack of qualified human resources also mattered. Several other papers including Samiee and Walters (2002) and Leonidou (2004) emphasised that market knowledge is a crucial obstacle in exporting for non-exporters and exporters alike.

${ }^{8}$ This happens due to a simple bargaining game between the buyer and the seller where not all interactions result in transactions; see the Online Appendix of Chaney (2014).
} 
measures the relative efficiency of remote versus local search. ${ }^{9}$ The change in the number of consumers firm $i$ has in location $x$ is described in the following difference equation:

$$
f_{i, t+1}(x)-f_{i, t}(x)=\sum_{k_{0}=1}^{\tilde{\gamma \mu}_{i}} \mathbb{1}\left[\tilde{x}_{i, k_{0}}=x\right]+\sum_{y \in S} f_{i, t}(y) \sum_{k_{y}=1}^{\widetilde{\gamma \mu \pi_{i, y}}} \mathbb{1}\left[\tilde{x}_{i, k_{y}}=x\right],
$$

where $f_{i, 0}(x)=0, \forall x \in S \equiv$ a discrete set of locations, $\mathbb{1}[$.$] is an indicator function, \widetilde{\gamma \mu}_{i}$ and $\widetilde{\gamma \mu \pi}_{i, y}$ are independent draws from their respective random variables $\widetilde{\gamma \mu}$ and $\widetilde{\gamma \mu \pi}$, and $\tilde{x}$ s are independent realisations from the probability distribution $g($.$) , where \operatorname{Pr}\left(\mathbb{1}\left[\tilde{x}_{i, k_{0}}=x\right]\right)=g(0, x)$ is the probability of finding a client from origin 0 in location $x .{ }^{10}$ The first part of the right-hand side of Equation (1) is the number of customers gained through local search, and the second part is the number of customers gained through remote search.

I modify Equation (1) by assuming that remote search is possible if and only if a firm already has a contact in that specific location, whether she be an existing customer or an existing supplier. The assumption that a firm can learn about potential clients from its existing suppliers is highly probable since the growth of the firm potentially boosts its suppliers' sales as well, creating an incentive for them to provide information. This results in the following equation that incorporates "supplier networks":

$$
f_{i, t+1}(x)-f_{i, t}(x)=\sum_{k_{0}=1}^{\tilde{\gamma \mu}_{i}} \mathbb{1}\left[\tilde{x}_{i, k_{0}}=x\right]+\left\{f_{i, t}(x)+s_{i, t}(x)\right\} \sum_{k_{x}=1}^{\widetilde{\gamma \mu \pi} \pi_{i, x}} \mathbb{1}\left[\tilde{x}_{i, k_{x}}=x\right],
$$

where $s_{i, t}(x)$ is the number of suppliers firm $i$ has in time $t$ in location $x$. The first part of the righthand side of Equation (2) is the same as in Equation (1) but now the second part shows that firms can acquire new customers in $x$ using both the existing clients and suppliers in $x$. Importantly, $\operatorname{Pr}\left(\mathbb{1}\left[\tilde{x}_{i, k_{x}}=x\right]\right)=g(x, x)$ is the probability of finding a client from $x$ in $x .^{11}$

The attentive reader might inquire whether the above methodology can also shed light on firms' search for suppliers using their existing network of clients. The short answer is no, since firms are assumed to always search for new clients to expand their sales, whereas this might not be the case in search for suppliers. However, in Appendix Section B, I show results that examine the effect of export experience on import entry and find a positive but not a robust relationship.

Note that another simple way to obtain a link between import experience and export entry at the country level is to assume that the fixed costs of exporting and importing share a component that proxies for country-specific variables such as customs procedures, language and culture. This way, a shock that causes a firm to import from a country would also make it more likely to export to that destination since it would have paid the shared component of fixed costs of trading with that country. Even though this would not generate a lagged structure as in Chaney (2014), results in this paper can be interpreted as a test for any type of market knowledge, and not necessarily network formation. In Section 5.3, I contrast this alternative mechanism with the "supplier network" hypothesis based on the results.

\footnotetext{
${ }^{9}$ The Online Appendix of Chaney (2014) details the micro-foundations of these variables.

${ }^{10}$ Chaney (2014) specifies a distribution for $g(y, x)$ in the form of $\alpha_{\lambda, y} G D P_{x} e^{x y / \lambda}$, where $\alpha_{\lambda, y}$ is a scaling constant and $\lambda$ measures the geographic dispersion of new contacts. This functional form implies that the probability depends on market size, distance, and dispersion. In reality, there might be additional factors such as cultural/linguistic similarity and institutional quality.

${ }^{11}$ Trivially, this would imply that the probability of finding a client in $x$ given the firm already has a contact in $x$ would not depend on distance since distance between $x$ and $x$ is zero.
} 


\section{2 | Specification}

Here, I adjust Equation (2) in order to have a testable empirical specification. Since I do not observe the number of customers a firm has, and can only observe whether the firm is exporting to or importing from a country, $f_{i, t}(x)$ and $s_{i, t}(x)$ are latent variables inferred from the binary $F_{i, c, t}$ and $S_{i, c, t}$, respectively (note that the notation for destination changes from location $x$ to country $c$ ):

$$
F_{i, c, t}=\left\{\begin{array}{ll}
1 & \text { if } f_{i, t}(x)>0, \\
0 & \text { if } f_{i, t}(x)=0,
\end{array} \quad S_{i, c, t}= \begin{cases}1 & \text { if } s_{i, t}(x)>0, \\
0 & \text { if } s_{i, t}(x)=0 .\end{cases}\right.
$$

Then, since the goal of this paper is to explain a firm's exporting to a specific country for the first time, $f_{i, t}(\mathrm{x})$ on the last part of Equation (2) is zero. In addition, I attribute the randomness of $\widetilde{\gamma \mu}_{i}$ and $\widetilde{\gamma \mu \pi}_{i, x}$ to firm-country-specific shocks that might be time-varying: $\varepsilon_{i, c, t}$. Plugging in the probability distributions $g\left(\right.$.) for $\operatorname{Pr}\left(\mathbb{1}\left[\tilde{x}_{i, k_{0}}=x\right]\right)$ and $\operatorname{Pr}\left(\mathbb{1}\left[\tilde{x}_{i, k_{x}}=x\right]\right)$ at country-level $c$, I get the following specification:

$$
F_{i, c, t+1}=\gamma \mu g(0, c)+\gamma \mu \pi S_{i, c, t} g(c, c)+\varepsilon_{i, c, t} .
$$

In order to partial out the effect of $S_{i, c, t}$, I use country-industry-time fixed effects to control for (a) $g($.) and (b) industry-specific trade costs, since these are additional sources of heterogeneity that can influence a firm's decision to export. Moreover, the empirical heterogeneous firms and trade literature have conclusively found that firm-specific productivity is an important predictor of exporting. ${ }^{12}$ This would mean that $\varepsilon_{i, c, t}$ in Equation (3) includes a firm-time-specific component. Hence, to control for time-varying productivity and other potential firm-level factors, I include firm-time dummies and get the following specification:

$$
F_{i, c, t}=\beta S_{i, c, t-1}+\delta_{c, n, t}+\zeta_{i, t}+\varepsilon_{i, c, t},
$$

where $\delta_{c, n, t}$ are country-industry-year fixed effects, $\zeta_{i, t}$ are firm-year fixed effects, and $\varepsilon_{i, c, t}$ are shocks that are possibly correlated within firm and country observations. To deal with this potential correlation, I cluster the standard errors multiway by firms and countries. ${ }^{13}$ The theoretical motivation presented in the previous section predicts that $\beta$ is positive.

\subsection{Identification strategy}

An important econometric concern with the specification in (4) is the possibility that the supplier and the client are the same firm and that the import/export relationship is merely an offshoring of a production stage. In that case, the decision to import and export are simultaneously determined but the actual transactions occur sequentially. In OLS estimations with fixed effects, I try to alleviate this issue by using 2-year lags but my main results are based on an IV strategy where importing is identified by the destination country's export supply, which is assumed to be exogenous to Turkish firms. More specifically, I use a shift-share instrument used by various papers such as Hummels, Jørgensen, Munch, and Xiang (2014) and Berman, Berthou, and Héricourt (2015), constructed in the following way:

\footnotetext{
${ }^{12}$ See Bernard, Jensen, Redding, and Schott (2012) for an extensive review of this literature.

${ }^{13}$ Cameron, Gelbach, and Miller (2011) explain that in cases where the errors are believed to be correlated across multiple non-nested groups, standard errors should be computed cluster-robust on those multiple dimensions.
} 


$$
\left.E X_{i, c, t}=\sum_{h} \sum_{d \neq T U R} \omega_{i, h} \text { (exports) }\right)_{c, d, h, t},
$$

and include the following control variable that proxies for firm-and destination-specific import demand:

$$
I M_{i, c, t}=\sum_{h} \sum_{d \neq T U R} \eta_{i, h}(\text { imports })_{c, d, h, t},
$$

where $d$ is destination country in (5) and source country in (6), $h$ is a 6-digit Harmonized System (HS6) product, $\omega_{i, h}$ is the initial weight (based on the first year of importing) of a product $h$ in a firm's imports during 2003-08, and $\eta_{i, h}$ is the initial weight of a product $h$ in a firm's exports over the same period. Alternatively, I use average and uniform (assigning equal weights to each product imported in 2003-08) weights as robustness checks. Also, I exclude Turkey as a destination and source country, again to minimise endogeneity. This strategy results in the following first and second stages which I estimate with two-stage least squares (2SLS):

$$
\begin{gathered}
S_{i, c, t-1}=\rho \ln E X_{i, c, t-1}+\theta_{2} \ln I M_{, i c, t}+\delta_{2 c, n, t}+\zeta_{2 i, t}+\varepsilon_{2 i, c, t-1}, \\
F_{i, c, t}=\beta \widehat{S_{i, c, t-1}}+\theta_{1} \ln I M_{i, c, t}+\delta_{1 c, n, t}+\zeta_{1 i, t}+\varepsilon_{1 i, c, t},
\end{gathered}
$$

where $\widehat{S_{i, c, t-1}}$ is the predicted value of import experience from (7), and all logs are created by adding 1 to the value before taking the log to avoid zeros. In addition, following Chaney's proposition that previous export experience from a country can increase the probability of entering a similar country, I include a region experience dummy in all regressions. For this, I assign a region to each country using the UN's 22 region classification system.

I estimate the 2SLS system using the linear probability model (LPM) due to the large number of fixed effects despite having a binary-dependent variable. ${ }^{14}$ Following Horrace and Oaxaca (2006), who explain that the potential bias (and inconsistency) of the LPM vanishes when all predicted probabilities lie in the unit interval, I check and confirm that the predicted values from all regressions lie in the $[0,1]$ range. ${ }^{15}$

\section{3 | DATA}

In this paper, I use two main data sets which were accessed at the Istanbul branch of the Turkish Statistical Institute under a confidentiality agreement. ${ }^{16}$ The first database is the longitudinal (2003-11) Foreign Trade Statistics that is based on official customs data at monthly frequency and it reports the value and quantity of a firm's imports and exports at the country-product (GTIP) level. ${ }^{17}$ I aggregate the data to annual frequency to eliminate seasonal effects and merge it with the second longitudinal (2003-11) firm-level data set, Industry and Services Statistics, to obtain

\footnotetext{
${ }^{14}$ Non-linear models produce inconsistent coefficients when faced with a large number of fixed effects due to the incidental parameters problem when $T$ is fixed; see Neyman and Scott (1948) and Lancaster (2000).

${ }^{15}$ These verifications are available on request.

${ }^{16}$ All analyses were completed there with only the output taken outside the premises after confidentiality checks.

${ }^{17}$ Turkey uses a 12-digit GTIP (Gümrük Tarife İstatistik Pozisyonu) classification of which the first eight digits correspond to the Combined Nomenclature $(\mathrm{CN})$ tariff schedule of the EU, and the first six digits correspond to the internationally standardised Harmonized System (HS).
} 
information about a firm's industry (based on 4-digit NACE classification). ${ }^{18}$ Note that the Industry and Services Statistics database comprises firms that have at least 20 employees, whereas the Foreign Trade Statistics data set includes all trading firms. ${ }^{19}$ Thus, I only include manufacturing firms that have at least 20 employees to be consistent. For the benchmark results, I drop years 2009-11 as this period corresponds to the Great Trade Collapse and its subsequent trade adjustment which might not be related to this study-these selections result in a sample of 17,327 manufacturing firms. ${ }^{20}$ Finally, I restrict the sample to 6,716 firms that have existed for the entire 2003-08 period and have imported and exported at least once to avoid entry/exit dynamics. In terms of destinations, I use the 191 countries that Turkey has traded with in 2003-08. After rectangularising the data set by firm-country-year, I drop observations where the firm has already exported to a country previously and get an unbalanced panel. Additional data I use include the following: GDP, development status indicators, migrant stock (from the Global Bilateral Migration database) and trade cost proxies (based on Doing Business: Trading across Borders) from the World Bank, distance and language proximity data from CEPII, ${ }^{21}$ and RTA data from De Sousa (2012). Trade data for the instruments are from COMTRADE (WITS).

Table 1 shows summary statistics for the 6,716 firms' exports and imports in panels (a) and (b), respectively. Note that the median number of countries (column (1)) served by a firm is 4 or 5 for both imports and exports, and this reveals that the median firm is a multidestination and multisource firm. The mean values (column (2)) are always larger than the median values indicating positive skewness, and confirms the well-established result that there are many small traders and a few large traders (there is concentration at the top even in this restricted sample of relatively large firms). Similarly, the median value (column (3)) of annual exports (imports) to a country is around 5,000 (4,000) Turkish liras in 2008-corresponding to about $\$ 4,000(\$ 3,000)$. The mean values (column (4)) are as much as 15 times as high for exports and 24 times as high for imports, again showing positive skewness. The number of exporters hovers around 63 to 69 per cent of the 6,716 firms, while the number of importers is about 74 to 79 per cent. Note also that these firms make up about 40 per cent of Turkey's total trade value. ${ }^{22}$ A caveat to mention here is that since the sample comprises large trading manufacturing firms that exist throughout the period, I am examining a group of highly productive firms. Table 2 shows that no sector dominates the sample of firms studied. Column (4) shows that all 23 manufacturing sectors are represented with the top three textiles, apparel, and food and beverages sectors making 17, 14 and 10 per cent of all firms. Columns (5) and (6) show the percentage of firms in a sector that export and import, respectively. Looking at sectors that make up more than 1 per cent of all firms, note how the export share

\footnotetext{
${ }^{18}$ I use the NACE (Nomenclature Statistique des Activités Économiques dans la Communauté Européenne) Rev. 1.1 classification system as reported.

${ }^{19}$ The Industry and Services Statistics also has firms that have $<20$ employees, but these were randomly surveyed and are not consistently included in the database. The total number of firms in the data set is 417,797 , of which 133,502 are manufacturers.

${ }^{20}$ As shown in Section 4.2, including 2009-11 does not change the results.

${ }^{21}$ As explained by Melitz and Toubal (2014), language proximity is a bilateral continuous index (from 0 to 1 ) based on four variables: (i) a dummy that indicates whether the countries' official languages are the same; (ii) the probability that two random people from the two countries speak the same language; (iii) the probability that two random people from the two countries speak the same native language; and (iv) the closeness of the countries' native languages based on the Ethnologue classification.

${ }^{22}$ The rest is shared between intermediaries, small firms $(<20$ employees) and firms that were born after 2003 and/or died before 2009 .
} 
TA B LE 1 Turkish Firms' Trade, 2003-08

(a) Exports

\begin{tabular}{|c|c|c|c|c|c|}
\hline Year & $\begin{array}{l}\text { (1) } \\
\text { Countries served } \\
\text { (median) }\end{array}$ & $\begin{array}{l}\text { (2) } \\
\text { Countries served } \\
\text { (mean) }\end{array}$ & $\begin{array}{l}\text { (3) } \\
\text { Value exported } \\
\text { (median) }\end{array}$ & $\begin{array}{l}(4) \\
\text { Value exported } \\
\text { (mean) }\end{array}$ & $\begin{array}{l}(5) \\
\text { No of } \\
\text { exporters }\end{array}$ \\
\hline 2003 & 4 & 7.25 & $\$ 1,443$ & $\$ 19,424$ & 4,256 \\
\hline 2004 & 4 & 7.62 & $\$ 1,731$ & $\$ 26,219$ & 4,445 \\
\hline 2005 & 4 & 7.95 & $\$ 2,005$ & $\$ 29,688$ & 4,569 \\
\hline 2006 & 5 & 8.37 & $\$ 2,485$ & $\$ 36,476$ & 4,615 \\
\hline 2007 & 5 & 8.80 & $\$ 3,073$ & $\$ 46,625$ & 4,581 \\
\hline 2008 & 5 & 9.21 & $\$ 3,860$ & $\$ 59,746$ & 4,540 \\
\hline \multicolumn{6}{|c|}{ (b) Imports } \\
\hline Year & $\begin{array}{l}\text { (1) } \\
\text { Countries sourced } \\
\text { (median) }\end{array}$ & $\begin{array}{l}\text { (2) } \\
\text { Countries sourced } \\
\text { (mean) }\end{array}$ & $\begin{array}{l}\text { (3) } \\
\text { Value imported } \\
\text { (median) }\end{array}$ & $\begin{array}{l}\text { (4) } \\
\text { Value imported } \\
\text { (mean) }\end{array}$ & $\begin{array}{l}(5) \\
\text { No of } \\
\text { importers }\end{array}$ \\
\hline 2003 & 4 & 6.35 & $\$ 1,774$ & $\$ 26,634$ & 4,966 \\
\hline 2004 & 4 & 6.62 & $\$ 2,137$ & $\$ 37,189$ & 5,182 \\
\hline 2005 & 5 & 6.84 & $\$ 2,145$ & $\$ 43,267$ & 5,234 \\
\hline 2006 & 5 & 6.99 & $\$ 2,438$ & $\$ 52,353$ & 5,270 \\
\hline 2007 & 5 & 7.21 & $\$ 2,817$ & $\$ 64,101$ & 5,290 \\
\hline 2008 & 5 & 7.29 & $\$ 3,168$ & $\$ 77,542$ & 5,136 \\
\hline
\end{tabular}

Notes: All figures relate to the 6,716 firms' trade with the 191 countries. Values are in US\$ and correspond to the total annual transaction of a firm with a country, converted from Turkish liras using annual average official exchange rates reported by the World Bank.

varies from larger than 80 per cent for electrical machinery and apparatus, motor vehicles, basic metals and chemicals to a low of 55 per cent for food and beverages; for imports, the share ranges from a high of $92 \%$ for chemicals to a low of $62 \%$ for publishing, printing and reproduction of recorded media and furniture.

Next, I present statistics on the countries that Turkish firms engage with. Note that two-way country relationships are highly common as 42 per cent of firms in the sample were both exporting to and importing from the same country in 2008. Figure 1 depicts the most popular export destinations and import sources served by Turkish firms during 2003-08 in panels (a) and (b), respectively. Note how the two panels have similar shadings; in fact, the correlation between the figures in the two panels is 0.6. The figure shows that Western Europe, Russia, Central Asia and the USA are top destinations, whereas Western Europe, China, India and the USA are top import sources. Table A1 in Appendix A shows the 191 countries sorted by how frequently they are served by Turkish firms and their characteristics including export/import probabilities, average entry rates, previous experience and gravity-type variables such as average GDP, distance to Turkey, language proximity to Turkish and whether an RTA was in effect with Turkey during anytime in 2003-08. I define export entry to a market as the first time a firm exports to a country. More precisely, since the data set starts from 2003, I take the earliest possible year of entry to be 2005. This 2-year margin helps alleviate the bias that might be introduced by sporadic exporting (e.g., a firm exporting to a country in 2002 (which I do not observe), then not exporting in 2003, and then exporting in 
TABLE 2 Sector characteristics

\begin{tabular}{|c|c|c|c|c|c|}
\hline NACE & $\begin{array}{l}\text { (2) } \\
\text { Sector }\end{array}$ & $\begin{array}{l}\text { (3) } \\
\text { No. of firms }\end{array}$ & (4) & $\begin{array}{l}\text { (5) } \\
\text { Share of } \\
\text { exporters }\end{array}$ & $\begin{array}{l}\text { (6) } \\
\text { Share of } \\
\text { importers }\end{array}$ \\
\hline 15 & Food and beverages & 664 & 0.10 & 0.55 & 0.67 \\
\hline 16 & Tobacco & 7 & $<0.01$ & 0.86 & 0.86 \\
\hline 17 & Textiles & 1,114 & 0.17 & 0.59 & 0.79 \\
\hline 18 & Apparel & 907 & 0.14 & 0.59 & 0.74 \\
\hline 19 & Leather and leather products & 165 & 0.02 & 0.63 & 0.78 \\
\hline 20 & Wood and wood products & 88 & 0.01 & 0.52 & 0.66 \\
\hline 21 & Paper and paper products & 163 & 0.02 & 0.78 & 0.88 \\
\hline 22 & $\begin{array}{l}\text { Publishing, printing and } \\
\text { reproduction of recorded media }\end{array}$ & 127 & 0.02 & 0.57 & 0.62 \\
\hline 23 & $\begin{array}{l}\text { Coke, refined petroleum } \\
\text { products and nuclear fuel }\end{array}$ & 10 & $<0.01$ & 0.70 & 0.90 \\
\hline 24 & Chemicals & 249 & 0.04 & 0.81 & 0.92 \\
\hline 25 & Rubber and plastics & 424 & 0.06 & 0.78 & 0.79 \\
\hline 26 & Other non-metallic minerals & 396 & 0.06 & 0.63 & 0.64 \\
\hline 27 & Basic metals & 264 & 0.04 & 0.82 & 0.86 \\
\hline 28 & Fabricated metals & 493 & 0.07 & 0.68 & 0.73 \\
\hline 29 & Machinery and equipment & 606 & 0.09 & 0.79 & 0.82 \\
\hline 30 & Office machinery and computers & 4 & $<0.01$ & 0.75 & 0.75 \\
\hline 31 & Electrical machinery and apparatus & 231 & 0.03 & 0.84 & 0.87 \\
\hline 32 & $\begin{array}{l}\text { Radio, TV and communication } \\
\text { equipment and apparatus }\end{array}$ & 43 & 0.01 & 0.77 & 0.91 \\
\hline 33 & $\begin{array}{l}\text { Medical, precision and optical } \\
\text { instruments, watches and clocks }\end{array}$ & 64 & 0.01 & 0.80 & 0.91 \\
\hline 34 & Motor vehicles & 285 & 0.04 & 0.82 & 0.85 \\
\hline 35 & Other transport equipment & 53 & 0.01 & 0.58 & 0.83 \\
\hline 36 & Furniture & 357 & 0.05 & 0.73 & 0.62 \\
\hline 37 & Recycling & 2 & $<0.01$ & 0.00 & 0.50 \\
\hline
\end{tabular}

Notes: NACE classification is Rev. 1.1 as reported. Share of total (column (4)) is calculated by dividing the number of firms in that sector (column (3)) by the total number of firms in the sample $(6,716)$ in 2008 (results for other years are similar). Share of exporters (column (5)) and importers (column (6)) are computed by dividing the number of exporting and importing firms by the number of firms in that sector, respectively. $<0.01$ indicates that the share is $<1$ per cent but positive.

2004 will not be considered an entry since I have a 2-year margin). In the estimations, my main independent variable for $S_{i, c, t-1}$ is a dummy for import status in the previous year. However, I also report results with a dummy for import entry in the previous year to see whether brand-new supplier relationships matter. As a third alternative, I use the number of accumulated importing years in the previous year as a proxy for the strength of the relationship with the supplier.

In Table A1, export/import probabilities are the percentage of 6,716 firms that serve or source from a country, averaged over the sample period. "Previous experience" (Import exp. and Export 
(a) Export status
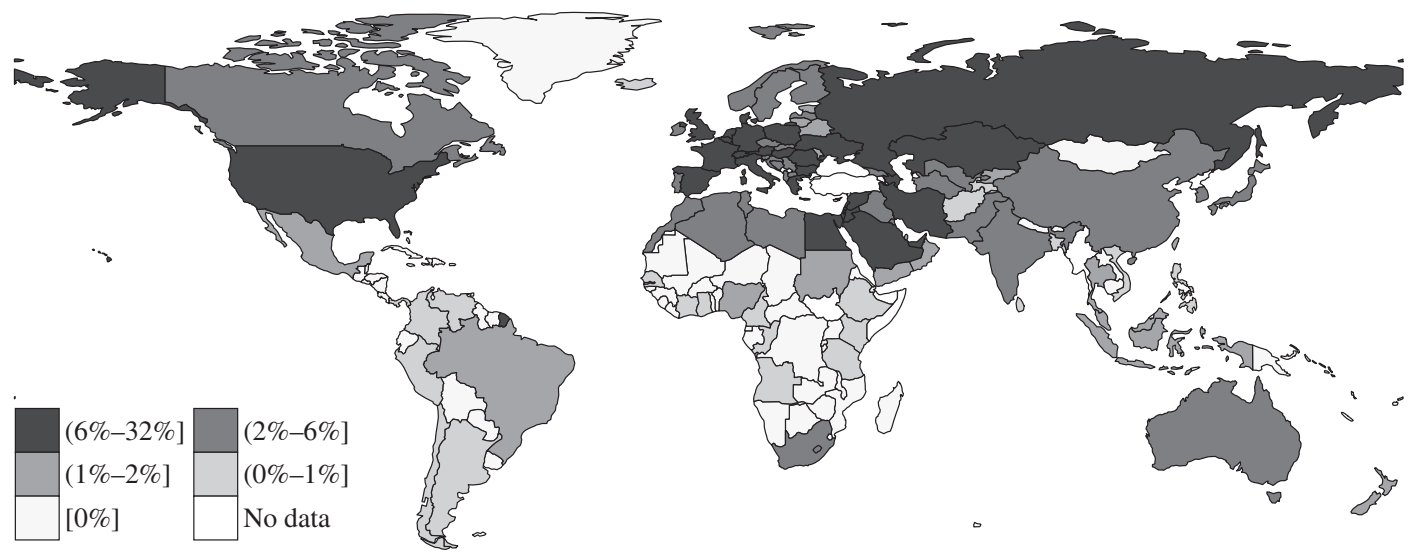

(b) Import status
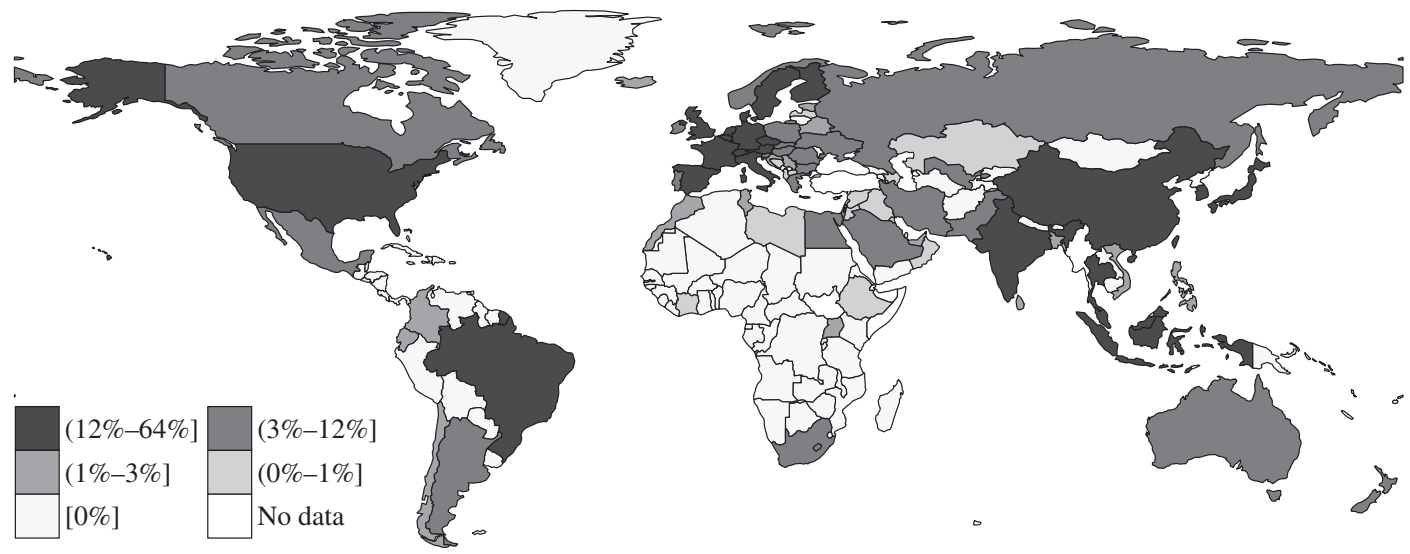

F I GURE 1 Popular export destinations and import sources

Notes: Export (import) status is the percentage of 6,716 firms that export to (import from) a country, averaged over the 2003-08 period. Darker shades indicate higher percentages. The correlation between export and import percentages at the country level is 0.6 .

exp. in Columns (10) and (11), respectively) is the percentage of entrants to a country that had trading experience with that country in the previous year. The table shows that there is substantial heterogeneity among countries in terms of entry and status rates: The top destination market is Germany with 32 per cent of firms serving that market on average, followed by Italy and Kazakhstan (21 per cent each), and United Kingdom (20 per cent). Interestingly, 86 countries are served by $<1$ per cent of firms. On the import side, the ranking is similar: Germany (50 per cent), Italy (44 per cent), China ( 28 per cent) and United Kingdom (27 per cent), with 126 countries being sourced by $<1$ per cent of firms. Regarding the probability of entering a market during 2005-08, Kazakhstan is the top "new" destination with 13 per cent entry probability.

Did new exporters to a country have previous import experience from that country? Simple calculations show that 15 per cent of new export-market entrants in 2005-08 had previous import experience from that country. Table A1 shows that these experience indicators show substantial heterogeneity. For instance, 39 per cent of firms that start exporting to Japan had previous import 
TABLE 3 Transitional probabilities

\begin{tabular}{lcccc|} 
Trade status $(\boldsymbol{t} / \boldsymbol{t}+\mathbf{1})$ & No trade & Import only & Export only & Two-way \\
\hline No trade & 98.41 & 0.71 & 0.82 & 0.06 \\
\hline Import only & 30.14 & 61.16 & 1.55 & 7.15 \\
\hline Export only & 31.35 & 1.44 & 61.23 & 5.98 \\
\hline Two-way & 6.49 & 16.57 & 14.63 & 62.31 \\
\hline
\end{tabular}

Notes: All figures relate to the 6,716 firms' trade with the 191 countries and are at the firm-country level. Column indicates $t$ and row indicates $t+1$.

experience from there, whereas only 10 per cent of firms that begin exporting to Russia had import experience from there. This type of heterogeneity indicates that local and remote search components might have complementarities that depend on destination characteristics such as distance.

To get a sense of the import-export dynamics at the firm-country level, I calculate transitional probabilities as shown in Table 3. Note the existence of hysteresis: a non-trader in year $t$ will be a non-trader in $t+198$ per cent of the time; on the other hand, a two-way trader in year $t$ will be a two-way trader in $t+162$ per cent of the time. What this paper is mainly interested is the transition from importing to exporting (and continue importing but not necessarily) to a country. Note that a non-trader is similarly likely to start importing or exporting from a country. However, a firm is more likely to export to a destination if it is first importing from that country relative to the case when it is not trading with that country at all $(1.55+7.15=8.70$ vs. $0.82+0.06=0.88$ percentage points). ${ }^{23}$

\section{4 | RESULTS}

\section{1 | OLS-FE results}

Before turning to the main empirical analysis with the IV, I run some exploratory OLS regressions by using alternating fixed effects $(F E)$ that progressively get stricter to show how the coefficient reacts. In all regressions, I include a proxy for the destination's firm-specific import demand (ln $\left.I M_{i, c, t}\right)$ and a region experience dummy. Note that the unconditional probability of export entry is 0.8 per cent in the sample, revealing that entry is very rare. Summary statistics for all variables including interaction terms to be used later can be found in Table A2 in the Appendix A.

Table 4 shows the OLS results with fixed effects getting stricter. Panel (a) has the results with 1-year lags, and panel (b) does a robustness check with 2-year lags. Each coefficient represents an estimate from a separate regression. The first column has firm-year and country-year dummies only, the second column has the set of preferred $F E$ with firm-year and country-industry-year dummies, and finally the third column has firm-year, country-year, and firm-country dummies that minimises variation but makes sure that results stay robust. ${ }^{24}$ Comparing columns (1) and (2) reveals that adding country-industry-year dummies does not change the estimated coefficients:

\footnotetext{
${ }^{23}$ For this analysis, I rectangularise the data set to have a balanced panel of 6,716 firms and 191 countries.

${ }^{24}$ Since there is a large number of fixed effects, I use the "high-dimensional" fixed effects ( $\left.H D-F E\right)$ approach proposed by Abowd and Kramarz (1999) and adjust it to three-way $H D-F E$ when using firm-country $F E$ following Carneiro, Guimarães, and Portugal's (2012) iterative method. All regressions were run using Sergio Correia's reghdfe command for STATA that allows including multiple $H D-F E$ at a relatively low cost of computing power.
} 
TABLE 4 OLS-FE results

\section{(a) One-year lags}

\begin{tabular}{|c|c|c|c|}
\hline$S_{i, c, t-1}$ & (1) & (2) & (3) \\
\hline \multirow[t]{2}{*}{ Import status } & $0.032 * * *$ & $0.032 * * *$ & $0.009 * * *$ \\
\hline & $(0.003)$ & $(0.003)$ & $(0.001)$ \\
\hline No. of obs. & $4,895,216$ & $4,895,216$ & $4,895,216$ \\
\hline$R^{2}$ & 0.05 & 0.10 & 0.56 \\
\hline \multirow[t]{2}{*}{ Import entry } & $0.017 * * *$ & $0.015^{* * *}$ & $0.003 * * *$ \\
\hline & $(0.002)$ & $(0.002)$ & $(0.001)$ \\
\hline No. of obs. & $3,655,951$ & $3,655,951$ & $3,655,951$ \\
\hline$R^{2}$ & 0.05 & 0.10 & 0.64 \\
\hline \multirow[t]{2}{*}{ Import years } & $0.012 * * *$ & $0.012 * * *$ & $0.023 * * *$ \\
\hline & $(0.001)$ & $(0.001)$ & $(0.002)$ \\
\hline No. of obs. & $4,895,216$ & $4,895,216$ & $4,895,216$ \\
\hline$R^{2}$ & 0.05 & 0.10 & 0.56 \\
\hline \multicolumn{4}{|c|}{ (b) Two-year lags } \\
\hline$S_{i, c, t-2}$ & (1) & (2) & (3) \\
\hline \multirow[t]{2}{*}{ Import status } & $0.029 * * *$ & $0.028 * * *$ & $0.003 * * *$ \\
\hline & $(0.003)$ & $(0.003)$ & $(0.001)$ \\
\hline No. of obs. & $4,895,216$ & $4,895,216$ & $4,895,216$ \\
\hline$R^{2}$ & 0.05 & 0.10 & 0.56 \\
\hline \multirow[t]{2}{*}{ Import entry } & $0.007 * * *$ & $0.006^{* * *}$ & -0.001 \\
\hline & $(0.002)$ & $(0.002)$ & $(0.002)$ \\
\hline No. of obs. & $2,427,474$ & $2,427,474$ & $2,427,474$ \\
\hline$R^{2}$ & 0.04 & 0.10 & 0.77 \\
\hline \multirow[t]{2}{*}{ Import years } & $0.013^{* * *}$ & $0.013^{* * *}$ & $0.021 * * *$ \\
\hline & $(0.001)$ & $(0.001)$ & $(0.002)$ \\
\hline No. of obs. & $4,895,216$ & $4,895,216$ & $4,895,216$ \\
\hline$R^{2}$ & 0.05 & 0.10 & 0.56 \\
\hline$F E$ & $\mathrm{FY}, \mathrm{CY}$ & $\mathrm{FY}, \mathrm{CNY}$ & $\mathrm{FY}, \mathrm{CY}, \mathrm{FC}$ \\
\hline
\end{tabular}

Notes: The dependent variable is $F_{i, c, t}$ (export-market entry). Each coefficient represents an estimate from a separate regression. All regressions include $\ln I M_{i, c, t}$ and a region experience dummy which are both positive and significant at the 1 per cent level (omitted in the table for brevity). Fixed effects ( $F E$ ) definitions are as follows: FY (firm-year), CY (country-year), CNY (country-industryyear) and FC (firm-country). Standard errors clustered multiway by firms $(6,716)$ and countries (191) in parentheses. ***, ** and * denote statistical significance at the 1,5 and 10 per cent levels, respectively.

Having a supplier in $c$ in $t-1$ increases the probability of export entry by 3.2 percentage points-a substantial magnitude since the unconditional export-market entry is only 0.8 per cent. Column (3) has the strictest specification that takes much of the meaningful variation away but still finds a positive and significant effect of about one percentage point, again larger than the mean entry probability. When I use import entry instead for $S_{i, c, t-1}$, I find that even in this strict definition, import entry to a country increases the probability starting to export to that country by 1.5 
percentage points in the preferred column (2). Reassuringly, even the coefficient in column (3) for import entry is positive and significant. The third alternative explanatory variable, the number of importing years, shows that an additional year of importing from a country increases the exportmarket entry probability by 1.2 percentage points in column (2). All coefficients have the expected positive sign and are significant at the 1 per cent level.

One can argue that a 1-year lag is too short to rule out the concern that a firm might make the decision of importing and exporting from a country in the same year but start exporting after importing which might happen in the next calendar year, and this would bias the coefficient upwards. To deal with this concern, I lag the explanatory variable by 2 years. Table 4 panel (b) shows that results stay qualitatively the same. More precisely, column (2) shows that a positive import status in $t-2$ increases export entry probability by 2.8 percentage points. Other experience variables are robust and the only coefficient that is not statistically significant is in column (3), where I have firm-country $F E$ and use the strictest experience variable of import-market entry in $t-2$, possibly limiting enough statistical variation.

For another way to gauge the importance of importing, I create dummies for 1, 2, 3, 4 and 5 years of continuous previous experience with a country. ${ }^{25}$ Column (1) of Table A3 in the Appendix A shows that even a single year of importing experience increases the likelihood of export-market entry by 1.4 percentage points, and it jumps to 4.9 percentage points for a firm with the maximum 5 years of experience. The coefficients increase in magnitude with the number of years and are all significantly different from each other except for between 4 and 5 years, indicating that there are diminishing returns to experience.

The OLS-FE results presented in this section hint at a positive relationship between import experience and export-market entry, but the concern for endogeneity entails that these results cannot be interpreted in a causal way. The next section uses the IV strategy described earlier to establish causality.

\subsection{IV results}

Table 5 shows the results with the IV strategy. Column (1) uses the benchmark instrument with initial weights and shows that lagged import status increases the probability of export-market entry by 11 percentage points-much larger than the 3.2 percentage points found without using an IV. Column (2), which instruments for import-market entry, shows that lagged import entry raises the export-market entry likelihood by 46 percentage points. ${ }^{26}$ Again, a striking result that seems to indicate that learning about a client from a supplier can be extremely fast. Column (3) shows that an additional year of importing increases the probability of market entry by 3 percentage points, larger than the 1.2 percentage point effect that was found earlier. These results suggest that the coefficients that were estimated with OLS were downward biased. One possible explanation for this is the measurement error of the binary $S_{i, c, t-1}$ in proxying for the number of suppliers a firm has in the destination country-by instrumenting it using 2 SLS, $\widehat{S_{i, c, t-1}}$ becomes a continuous variable that is potentially better at predicting the size of a firm's supplier network. ${ }^{27}$

\footnotetext{
${ }^{25}$ Five years is the maximum number of experience years allowed by the sample period (2003-08). Note that five here means at least five years as I do not observe the earlier periods.

${ }^{26}$ Note that the import entry dummy in Column (2) equals one only when the firm starts importing from that country for the first time. In unreported estimations, I include import re-entries on the right-hand side and the results do not change.

${ }^{27}$ In all 2SLS regressions, like I did for OLS regressions, I confirm that predicted probabilities lie in the unit interval.
} 


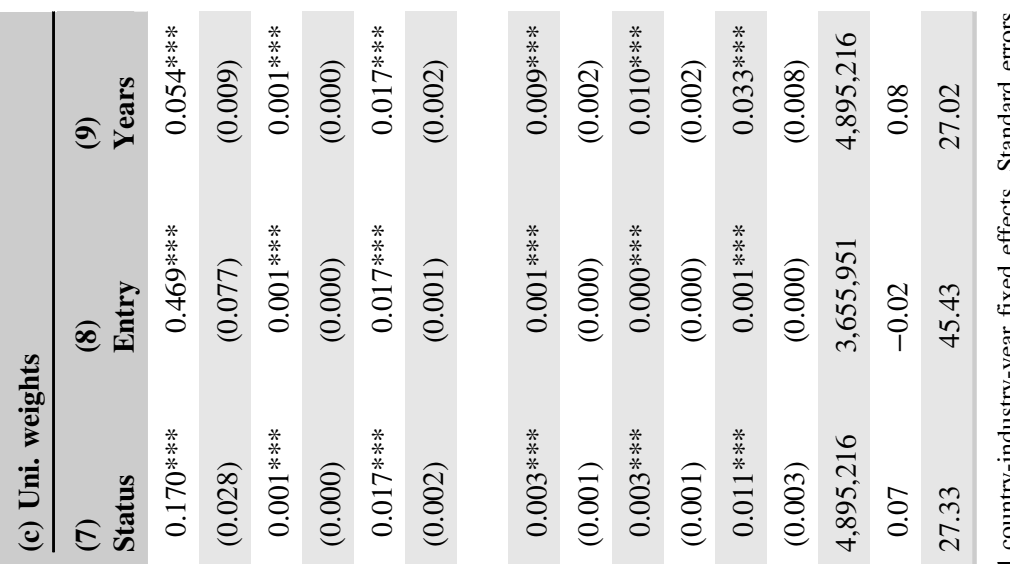

题

密

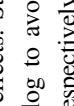

要

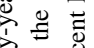

鄫

宽

密

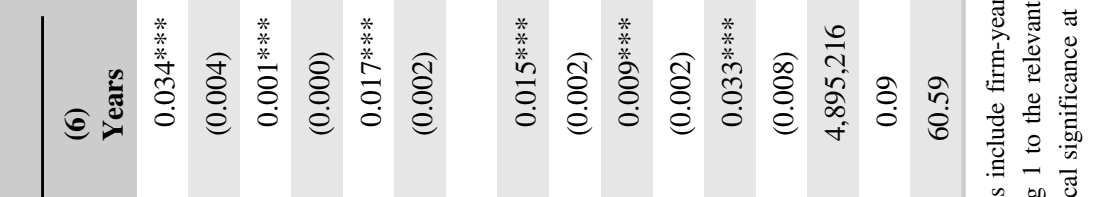

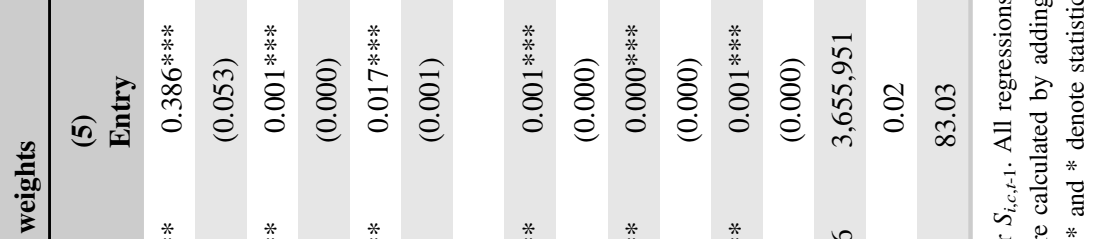

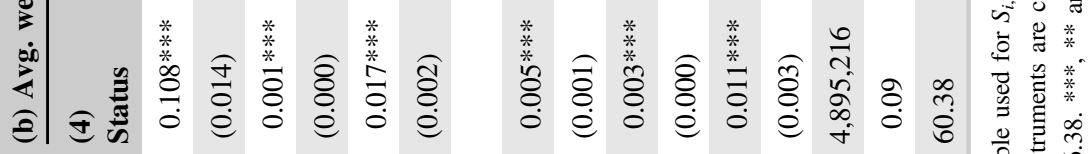

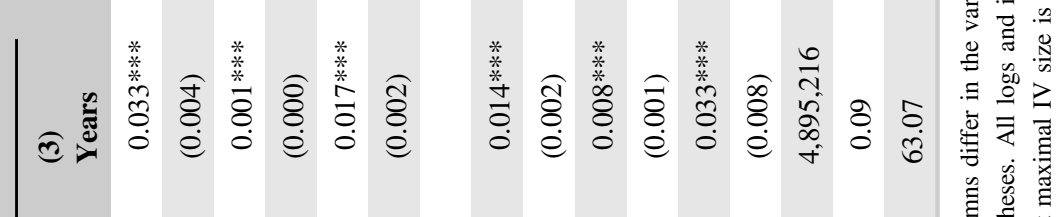

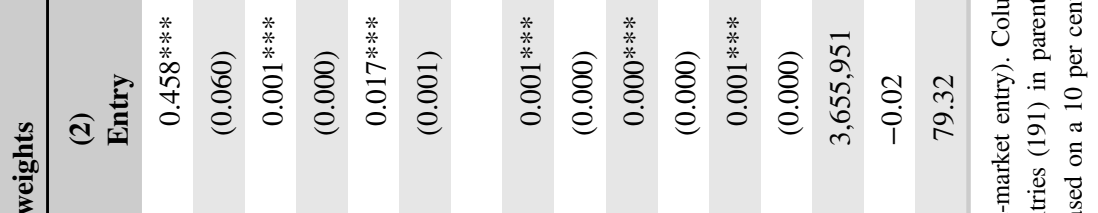

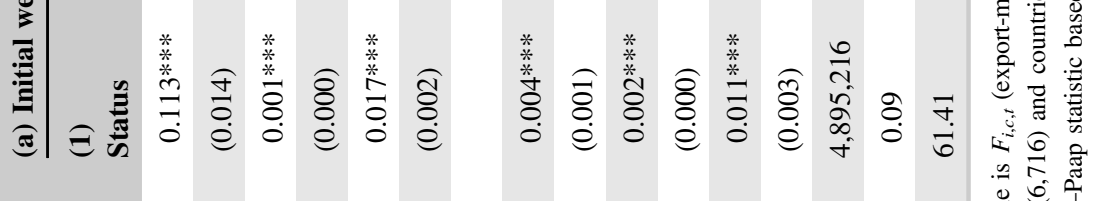


Columns (4-6) and (7-9) of Table 5 use average and uniform weights, respectively, as sensitivity analyses and find that results are robust with coefficients that are similar in magnitude. In all columns, I find that lagged imports of the country from the rest of the world, which proxies for demand shocks, increase the probability of export-market entry as expected. Similarly, the region experience dummy is statistically significant and has a consistent effect of 1.7 percentage points; however, a comparison between this variable and the import experience dummy shows that they are statistically different from each other revealing that same-country import experience is more important than similar-country export experience. The $F$-stat form of the Kleibergen-Paap statistic, which measures the strength of the instruments, is always higher than the critical value of 16.38 based on a 10 per cent maximum IV size. ${ }^{28}$ The first-stage results depicted in the lower half of Table 5 indicate that the instrument is statistically significant at the 1 per cent level in all specifications.

Table 6 does several sensitivity analyses to the main results in columns (1-3) of Table 5. Column (1) excludes EU countries from the sample since the formation of the EU-Turkey

TABLE 6 IV Sensitivity analysis

\begin{tabular}{lccccccc} 
& $\mathbf{( 1 )}$ & $\mathbf{( 2 )}$ & $\mathbf{( 3 )}$ & $\mathbf{( 4 )}$ & $\mathbf{( 5 )}$ & $\mathbf{( 6 )}$ & $\mathbf{( 7 )}$ \\
\hline$S_{i, c, t-1}$ & w/o EU & w/o small & w/o 2008 & w/ 2009-11 & $\begin{array}{c}\text { One-year } \\
\text { margin }\end{array}$ & $\begin{array}{c}\text { Two-year } \\
\text { lags }\end{array}$ & intermed. \\
\hline Import status & $0.112^{* * *}$ & $0.096^{* * *}$ & $0.115^{* * *}$ & $0.111^{* * *}$ & $0.118^{* * *}$ & $0.117^{* * *}$ & $0.037^{* * *}$ \\
& $(0.020)$ & $(0.014)$ & $(0.014)$ & $(0.014)$ & $(0.014)$ & $(0.014)$ & $(0.007)$ \\
\hline No. of obs. & $4,274,906$ & $4,278,239$ & $3,686,043$ & $6,511,046$ & $6,147,107$ & $4,895,216$ & 807,601 \\
\hline$R^{2}$ (centred) & 0.08 & 0.10 & 0.09 & 0.10 & 0.08 & 0.09 & 0.05 \\
\hline KP stat. & 36.42 & 60.20 & 62.21 & 72.66 & 61.54 & 62.45 & 84.16 \\
\hline Import entry & $0.456^{* * *}$ & $0.380^{* * *}$ & $0.428^{* * *}$ & $0.545^{* * *}$ & $0.425^{* * *}$ & $0.416^{* * *}$ & $0.255^{* * *}$ \\
\hline No. of obs. & $3,196,855$ & $3,193,300$ & $2,446,778$ & $5,557,353$ & $4,895,216$ & $2,427,474$ & 603,865 \\
\hline$R^{2}$ (centred) & -0.01 & 0.02 & -0.01 & -0.04 & -0.01 & -0.01 & -0.01 \\
\hline KP stat. & 41.59 & 75.15 & 80.91 & 114.46 & 81.32 & 80.23 & 166.64 \\
\hline Import years & $0.033^{* * *}$ & $0.029 * * *$ & $0.040^{* * *}$ & $0.023^{* * *}$ & $0.041^{* * *}$ & $0.049 * * *$ & $0.012^{* * *}$ \\
\hline No. of obs. & $4,274,906$ & $4,278,239$ & $3,686,043$ & $6,511,046$ & $6,147,107$ & $4,895,216$ & 807,601 \\
\hline$R^{2}$ (centred) & 0.09 & 0.10 & 0.09 & 0.10 & 0.10 & 0.09 & 0.06 \\
\hline KP stat. & 38.32 & 61.85 & 63.39 & 73.74 & 63.79 & 64.33 & 78.92 \\
\hline
\end{tabular}

Notes: The dependent variable is $F_{i, c, t}$ (export-market entry). Each coefficient represents an estimate from a separate 2 SLS regression. All regressions include $\ln I M_{i, c, t}$ and a region experience dummy which are both positive and significant at the 1 per cent level. All regressions include firm-year and country-industry-year fixed effects $(F E)$. Standard errors clustered multiway by firms (6,716, except for columns (4) and (7) where the number of firms is 5,153 and 1,094, respectively) and countries (191, except for columns (1) and (2) where the number of countries is 164 and 168, respectively) in parentheses. The critical value for KleibergenPaap (KP) statistic based on a 10 per cent maximal IV size is 16.38 . First-stage results are omitted for brevity. ***, ** and * denote statistical significance at the 1,5 and 10 per cent levels, respectively.

\footnotetext{
${ }^{28}$ This statistic is a version of the Cragg-Donald statistic adjusted for clustered standard errors.
} 
Customs Union in 1995 had caused many Turkish firms to be entrenched in European supply chains, possibly diminishing the role of the "learning from supplier" hypothesis by 2003-08. Column (1) indicates that excluding the EU does not affect the results. Column (2) excludes countries that have less than \$1B average GDP over the 2003-08 period, as the learning mechanisms in these small countries might be quite distinct: even though they have a lower number of potential clients, the importance of knowing a supplier might be more crucial in accessing small-sized networks. Results show that excluding these countries does not change the statistical significance of the coefficients but the magnitudes slightly decrease. Column (3) leaves out the year 2008 as the second half of 2008 corresponds to the beginning of the Great Trade Collapse, and the coefficients are qualitatively the same. Column (4) includes three additional years (2009, 2010 and 2011), and the coefficients remain positive and significant, with similar magnitudes. ${ }^{29}$

In column (5), I change the definition of entry and require only a 1 -year margin, meaning the earliest entry can be in 2004. This adds more than a million observations to the benchmark sample and the coefficients stay qualitatively the same. In column (6), I use 2-year lags as I did in the OLS-FE section and find that results are robust. Finally, in column (7), I replace my sample of manufacturing firms with the set of non-manufacturing intermediary firms. These are firms whose 4-digit NACE industry is listed as trade wholesaler or trade retailer in the Industrial and Services Statistics Database. ${ }^{30}$ Since these firms do not manufacture and simply search for export/import markets to expand, the $\beta$ coefficient is less likely to be confounded by supply-chain linkages. As shown in Column (7), even though I have less than a million observations due to having only 1,094 firms, the results are robust, albeit with lower magnitudes-lagged import status increases the probability of market entry by 3.7 percentage points for intermediaries. ${ }^{31}$ This result implies that the learning mechanism might be quite different between manufacturing and non-manufacturing firms. One explanation for this finding is due to intermediaries trading more homogeneous products as shown by Bernard, Grazzi, and Tomasi (2015) for Italian firms. ${ }^{32}$ As will be shown in Section 5.2, the "market knowledge" effect is larger when the basket of goods imported includes more differentiated products and/or more inputs.

\section{3 | Robustness: Multiple IVs}

Thus far I have shown that instruments are strong but only assumed that they are exogenous. To be more convinced that they do satisfy the exclusion restriction, I add a second instrument based on Turkey's tariffs to the 2 SLS system in (7) and $(8),{ }^{33}$ it is defined in the following form:

\footnotetext{
${ }^{29}$ Estimating the specification in column (4) with a crisis interaction (dummy for 2009-11) does not result in a significant interaction term, albeit the main effect stays positive and significant.

${ }^{30}$ Like I did for manufacturing firms, I make sure that these intermediaries existed for the entire $2003-08$ period to avoid entry/exit dynamics.

${ }^{31}$ For column (7), I use firm-year and country-year $F E$ since all firms are in the same "intermediary" industry disallowing me to use country-industry-year $F E$.

${ }^{32}$ In fact, the Turkish data also reveal that manufacturers import more differentiated products and more inputs when compared to intermediaries (wholesalers and retailers).

${ }^{33}$ I get MFN and preferential tariff data at the country-HS6 level from COMTRADE (WITS).
} 


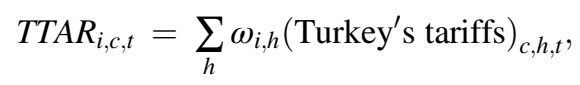

and I add the relevant additional control variable based on destination tariffs faced by Turkish exporters:

$$
D T A R_{i, c, t}=\sum_{h} \eta_{i, h}(\text { destination tariffs })_{c, h, t},
$$

where I use initial weights are as before. Intuitively, (9) measures the weighted average bilateral tariff imposed by Turkey on the set of products a firm has imported, and (10) is the weighted average bilateral tariff faced by a Turkish firm on the set of products that it has exported. I exclude

\begin{tabular}{|c|c|c|c|}
\hline & (1) & (2) & (3) \\
\hline & Status & Entry & Years \\
\hline \multirow[t]{2}{*}{$S_{i, c, t-1}$} & $0.055^{* * *}$ & $0.263 * *$ & $0.015^{* * *}$ \\
\hline & $(0.021)$ & $(0.111)$ & $(0.006)$ \\
\hline \multirow[t]{2}{*}{$\ln (I M)_{i, c, t}$} & $0.000 * * *$ & $0.000 * * *$ & $0.000 * * *$ \\
\hline & $(0.000)$ & $(0.000)$ & $(0.000)$ \\
\hline \multirow[t]{2}{*}{$\ln (D T A R)_{i, c, t}$} & $-0.005 * * *$ & $-0.004 * * *$ & $-0.005 * * *$ \\
\hline & $(0.001)$ & $(0.002)$ & $(0.001)$ \\
\hline \multirow[t]{2}{*}{ Region experience $_{i, c, t-1}$} & $0.017 * * *$ & $0.016 * * *$ & $0.017 * * *$ \\
\hline & $(0.002)$ & $(0.001)$ & $(0.002)$ \\
\hline \multicolumn{4}{|l|}{ First-stage } \\
\hline \multirow[t]{2}{*}{$\ln (E X)_{i, c, t-1}$} & $0.003 * * *$ & $0.000 * * *$ & $0.009 * * *$ \\
\hline & $(0.000)$ & $(0.000)$ & $(0.002)$ \\
\hline \multirow[t]{2}{*}{$\ln (T T A R)_{i, c, t-1}$} & -0.006 & 0.008 & -0.022 \\
\hline & $(0.040)$ & $(0.011)$ & $(0.136)$ \\
\hline \multirow[t]{2}{*}{$\ln (I M)_{i, c, t}$} & 0.000 & 0.000 & 0.000 \\
\hline & $(0.000)$ & $(0.000)$ & $(0.000)$ \\
\hline \multirow[t]{2}{*}{$\ln (D T A R)_{i, c, t}$} & $0.012 * * *$ & 0.002 & $0.037 * * *$ \\
\hline & $(0.004)$ & $(0.002)$ & $(0.014)$ \\
\hline \multirow[t]{2}{*}{ Region experience $_{i, c, t-1}$} & $0.006^{* *}$ & 0.000 & $0.017 * *$ \\
\hline & $(0.002)$ & $(0.000)$ & $(0.007)$ \\
\hline No. of obs. & $3,111,393$ & $2,341,262$ & $3,111,393$ \\
\hline$R^{2}$ (centred) & 0.002 & 0.000 & 0.003 \\
\hline Kleibergen-Paap stat. & 19.24 & 30.18 & 18.88 \\
\hline Hansen $p$-value & 0.77 & 0.62 & 0.78 \\
\hline
\end{tabular}

T A B LE 7 Multiple IVs

Notes: The dependent variable is $F_{i, c, t}$ (export-market entry). Columns differ in the variable used for $S_{i, c, t-1}$. All regressions include firm-year and country-industry-year fixed effects. Standard errors clustered multiway by firms $(5,506)$ and countries (150) in parentheses. EU countries are dropped in order to have meaningful variation in the tariff instrument. All logs and instruments are calculated by adding 1 to the relevant value before taking the log to avoid zeros. The critical value for Kleibergen-Paap statistic based on a 10 (15) per cent maximal IV size is 19.93 (11.59). ***,** and $*$ denote statistical significance at the 1,5 and 10 per cent levels, respectively. 
EU countries from this analysis as the existence of the customs union implies that tariff changes between EU and Turkey are de minimis, limiting statistical variation.

The system I estimate for export-market entry with two instruments becomes the following:

$$
S_{i, c, t-1}=\rho \ln E X_{i, c, t-1}+\theta_{2} \ln I M_{i, c, t}+\lambda \ln T T A R_{i, c, t-1}+\tau_{2} \ln D T A R_{i, c, t}+\delta_{2 c, n, t}+\zeta_{2 i, t}+\varepsilon_{2 i, c, t-1},
$$

$$
F_{i, c, t}=\beta \widehat{S_{i, c, t-1}}+\theta_{1} \ln I M_{i, c, t}+\tau_{1} \ln D T A R_{i, c, t}+\delta_{1 c, n, t}+\zeta_{1 i, t}+\varepsilon_{1 i, c, t} .
$$

Table 7 shows the results; importantly, the Hansen $p$-values are comfortably higher than 0.10 , which means that the exogeneity of the chosen instruments cannot be rejected. The KleibergenPaap (KP) statistics are not as high as in Table 5, but they are sufficiently large for inference. Column (1) shows that previous import experience increases the probability to start exporting by 5.5 percentage points, about half the magnitude found with a single IV, but still higher than the OLSFE results. Similarly, the coefficients of 26 and 1.5 percentage points in columns (2) and (3) are lower than their corresponding results with a single IV. Note that the first-stage results in Table 7 indicate that Turkey's tariffs are often not significant predictors of importing, whereas destination tariffs play a role in export entry. Overall, these findings establish that a conservative estimate of the effect of lagged import status on export entry is 5.5 percentage points.

\section{5 | HETEROGENEOUS EFFECTS AND DISCUSSION ON MECHANISMS}

After establishing that having a supplier in the destination makes a firm more likely to start selling to that country, I now explore what contributes to this learning from suppliers. More specifically, I analyse whether local and remote search for clients have complementarities that depend on destination, firm and product characteristics, making the probability distribution $g($.) a function of additional variables. ${ }^{34}$ The following two subsections explore these heterogeneities by using both OLS-FE and the IV strategy. ${ }^{35}$ Based on these results, I discuss potential mechanisms in the third subsection.

\section{1 | Country characteristics}

As detailed in Table A1 in the Appendix A, there is substantial country heterogeneity in the data. In this section, I take advantage of this dimension by interacting the experience variable with six gravity-type measures: GDP, distance to Turkey, language proximity to Turkish, whether the country has an RTA with Turkey, development status and an ease of trade dummy. ${ }^{36}$ The GDP proxies for the size of network that the initial supplier contact has access to in a given country, and this is expected to increase the probability of the firm to find a client. If there are complementarities

\footnotetext{
${ }^{34}$ As Cavusgil and Zou (1994) and Tesfom and Lutz (2006) emphasise, the nature of export barriers largely depends on host-market and industry characteristics.

${ }^{35}$ Summary statistics for all interaction variables can be found in Table A2 in Appendix A.

${ }^{36}$ To create the ease of trade dummy, I divide the set of countries into two groups based on the median distance-to-frontier score (based on time and cost of trading-higher scores indicate lower fixed trade costs) reported by the World Bank's Doing Business: Trading across Borders. For each country, I use the score for the first reported year in 2006-14. Dividing the countries into quartiles does not change the results.
} 
between local and remote search, one might argue that firms would be more likely to start exporting to closer destinations, even when they have a supplier contact. ${ }^{37}$ Language proximity is also expected to increase the probability of export-market entry as this would enable the firm to ease its way into the network of clients that can be accessed through the supplier. For RTAs, which have been found to increase bilateral trade between countries, the effect of importing on export entry is not clear-cut since RTAs might erode informational barriers and thus eliminate the need to having an initial contact in the destination country in order to access clients. ${ }^{38}$ On the other hand, development status, which proxies for institutional quality and thus the fluidity of networks, is expected to increase the likelihood of export-market entry given that a firm has a supplier. Finally, the ease of trade dummy that indicates whether trading with that country (whether it be exporting or importing) is relatively smooth can reveal whether the effect of import experience depends on trade costs; if the effect is indeed stronger for destinations with larger trade costs, then this would give support to the "shared fixed costs" hypothesis. ${ }^{39}$

Table 8 panel (a) has the OLS-FE results, and panel (b) has the corresponding IV results. Columns (1) and (6) show that the coefficients on GDP and distance are both significant with the predicted signs. This result is not surprising since there are more export opportunities in larger countries that can be accessed easily given having a supplier, and export entry should be more likely in more proximate countries that enable smoother communication and frequent interactions with the existing supplier. However, the IV strategy turns the statistically insignificant coefficient on language proximity to significant and positive - this implies that linguistic (or cultural) proximity does smooth learning. In addition, the coefficient on RTA is negative in the IV results-one might argue that signing an RTA substitutes for having an initial contact as client networks become readily accessible with information generated by RTAs. To give a clearer interpretation, back-of-the-envelope calculations based on column (6) indicate that having an existing supplier in Russia increases the probability of starting to export there by 15 percentage points more than the analogous effect for the USA, as Russia's proximity to Turkey more than offsets for its smaller market size. Moreover, the effect for Russia is 8 percentage points larger than the one for Turkey's top trading-partner Germany, where the import experience effect is abated by the existence of the EU-Turkey Customs Union. Small and distant countries often have much lower effects, with import experience from Thailand having a 17 percentage points lower effect than the one for Germany. A small country with a substantial import experience effect is Kazakhstan with only a percentage point less than Russia's, thanks to the similarity of Kazakh to Turkish.

In Column (2), I interact previous importing with development status indicators and find that the effect is non-existent for low-income countries (the omitted category), and significant and positive for all other countries. This result is confirmed in Column (7) with the IV strategy, and the equality of the coefficients for the three groups cannot be rejected at the 5 per cent level. This result reveals that having a supplier helps only in higher income countries, perhaps due to the rigidity of business networks in low-income countries. In Columns (3) and (8), I interact previous importing with a dummy that equals one if the country is ranked above the median in terms of ease of trade, using OLS and IV, respectively. The interactions are not significant, revealing that import experience is important for export-market entry regardless of trade costs.

\footnotetext{
${ }^{37}$ This would be the case if the probability distribution $g($.$) is a function of home location regardless of the location of previ-$ ous contacts, as in $g(0, y, x)$.

${ }^{38}$ See Baier and Bergstrand (2007) and Baier, Bergstrand, and Feng (2014) who establish that signing RTAs increases bilateral trade using frontier econometric techniques with the gravity equation.

${ }^{39}$ I thank an anonymous referee for this suggestion.
} 


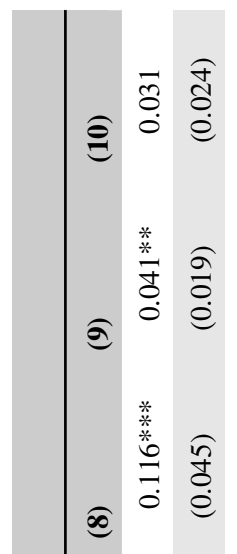

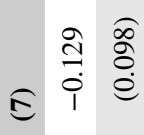

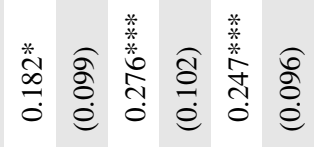

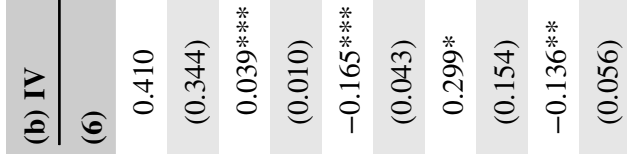

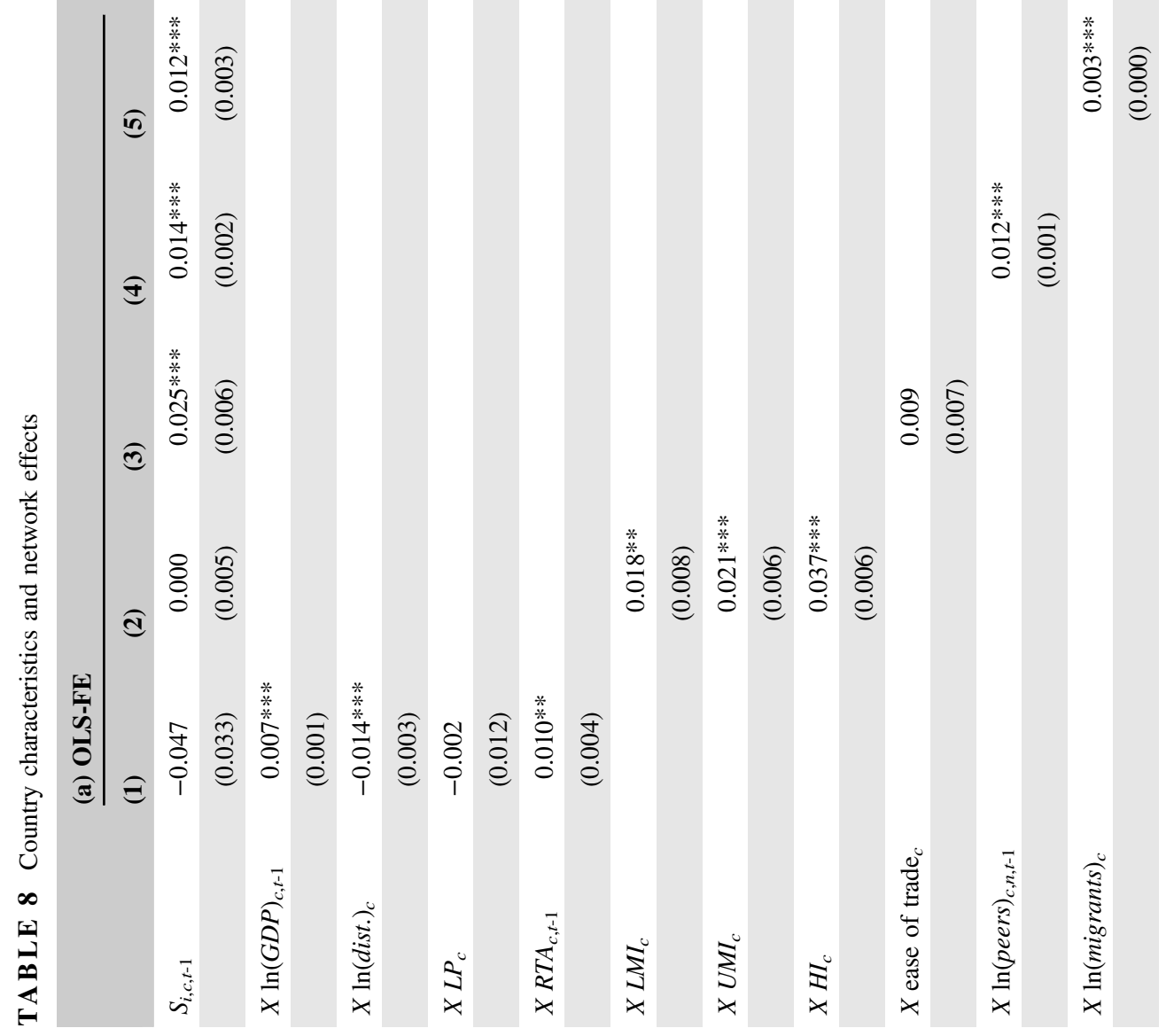




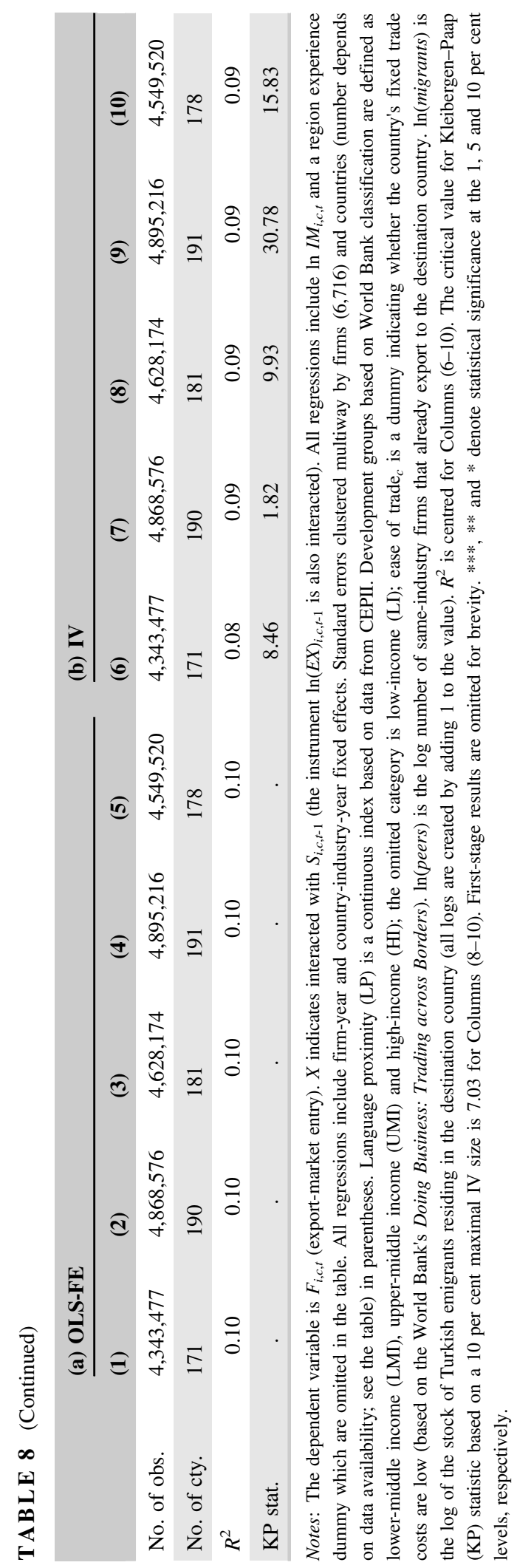


In the rest of the table, following the literature on network effects, I examine whether having (a) same-industry Turkish firms that already export to that destination (number of "peers"), and (b) a sizable Turkish immigrant community in the destination country matter. Both of these variables are expected to increase the probability of export-market entry as both should erode informational barriers. Table 8 Columns (4) and (9) show that experience matters regardless of whether there are any existing peers. Nonetheless, the number of peers does increase the probability of market entry once interacted with previous importing-Column (9) indicates that a one standard deviation (0.871) increase in $\ln$ (peers) increases the probability of export-market entry by 4 percentage points when interacted with previous import experience. Similarly, Columns (5) and (10) show that the size of the Turkish immigrant community matters. Interestingly, Column (10) with the IV strategy reveals that having a supplier is not helpful unless there is a Turkish immigrant community in the destination country. ${ }^{40}$

\subsection{Firm and product characteristics}

In this subsection, I examine firm and product characteristics that proxy the strength of the firm's relationship with its supplier. The variables I consider are value of imports, number of HS6 products imported, the value share of the country in a firm's total imports, the share of differentiated (both horizontally and vertically) products in a firm's imports, ${ }^{41,42}$ the share of intermediates in a firm's imports, ${ }^{43}$ and the share of imports that embody medium or high technology." 44 All of these variables are expected to increase the probability of export-market entry as they predict closer supplier-buyer relationships. A "tighter" relationship should lead a firm to spend more time and effort with that supplier resulting in a higher likelihood to learn about a client. Similarly, trading of differentiated products as well as technology-embodied goods might require a closer relationship and enhance the transmission of market knowledge learned through importing. In addition, I conjecture that importing an input, which goes into the firm's production function, might generate larger learning effects due to its higher importance than, for instance, a final good. Note that I am not using interactions here as these variables are firm-specific, making them potentially endogenous. Using import experience interactions would require additional instruments to identify the interactions. I avoid this issue by simply replacing the lagged import experience dummy with the variable in question; this is a caveat to bear in mind when interpreting the coefficients.

\footnotetext{
${ }^{40}$ The largest Turkish immigrant community is in Germany with about a 2 million inhabitants in 2000 (the latest year of data availability from the World Bank). Non-European countries such as USA, Saudi Arabia and Israel also had sizable Turkish immigrant communities in 2000.

${ }^{41}$ I classify horizontally differentiated versus non-differentiated goods based on the index created by Rauch. He assigns a heterogeneity value (w: homogeneous goods, r: reference priced goods and n: differentiated goods) for each Standard International Trade Classification (SITC) Rev.2 industry. I concord that to HS6 products using concordance tables provided by the UN Statistics Division and bundle homogeneous and reference priced goods together as non-differentiated products. Results reported are with Rauch's conservative definition but using the liberal definition does not change the results.

${ }^{42}$ I proxy for a product's scope for vertical (or quality) differentiation using Khandelwal's (2010) "quality ladders." By examining prices and market shares of US imports at the product level, Khandelwal computes "quality ladders" for each HS10. I concord the HS10 data to HS6 (using a weighted average measure of ladders) and divide products into two groups based on the median of this measure.

${ }^{43}$ Products (HS6) are labelled as intermediates according to the Broad Economic Categories (BEC) classification.

${ }^{44}$ I concord Lall's (2000) classification at the SITC level to HS6 to label products that embody medium or high technology. This classification is similar to the one by Hatzichronoglou (1997) which is at the International Standard Industrial Classification (ISIC) level, but I use Lall (2000) since SITC is based on traded manufactured products.
} 
Table 9 panel (a) has the OLS-FE results, whereas panel (b) has the IV results. A glance at the two panels reveals that the coefficients have the expected positive signs with the IV magnitudes larger than the OLS-FE magnitudes as in the main results. I focus on panel (b) for inference. The Kleibergen-Paap statistics are comfortably larger than the critical value of 16.38 in all columns, indicating that the instrument is strong enough to predict these continuous variables as well. Column (1) shows that a one standard deviation (1.503) increase in $\ln$ (imports) increases entry probability by 1.5 percentage points. Column (2) has a similar interpretation: a one standard deviation (0.162) increase in $\ln$ (no. of prod.) raises the probability of export-market entry by 1.8 percentage points. Column (3) shows that a country's share in a firm's imports matters in determining that firm's export expansion. A one standard deviation (0.040) increase in this share increases exportmarket entry probability by 2.04 percentage points. Column (4) reveals that a firm that imports only differentiated products from a country is much more likely to start exporting to that country when compared to a firm that imports entirely homogeneous or reference priced goods. This result is similar in column (5) where the right-hand side is replaced by the share of imports that have scope for quality differentiation. Column (6) indicates that an importer of mostly intermediate goods would be more likely to start exporting to that country; in this case, a one standard deviation increase has a 1.67 percentage point effect. Finally, column (7) proxies for the "closeness" of the relationship with the supplier using the share of imports that embody technology and find a positive and significant effect on export-market entry.

Note that these regressions are not able to clearly identify the additional effect of the variables since they are not interactions with the binary import experience variable. Even though the variables have a positive effect on export-market entry, the absence of suitable additional instruments in this case means that the firm and product characteristics results should be interpreted with caution.

\section{3 | Discussion on mechanisms}

The results in Section 4 show that a firm's previous experience importing from a country increases its probability to export to that country, and a conservative estimate of this effect is 5.5 percentage points. This result is robust to several sensitivity checks but does not identify the causal channel. The theoretical motivation in Section 2.1 describes a setting where firms learn about potential clients from their existing suppliers in the same country. This occurs as suppliers have an incentive to provide information about potential clients to their direct client, since this would potentially boost their sales as well. This "supplier network" hypothesis is the leading explanation behind the empirical results. An alternative explanation is that the fixed costs of exporting and importing share a country-specific component, enabling the firm to start exporting to a destination once it has paid a part of the fixed cost through importing from that same country. This component might proxy for variables such as customs procedures, language and culture. In this subsection, based on the results in Sections 4, 5.1 and 5.2, I discuss whether this alternative mechanism can also explain the patterns we see in the data.

Comparing the results in Sections 4.1 and 4.2 reveals that the IV coefficients are larger than the OLS coefficients. This implies that the import status dummy is a weak proxy for the number of suppliers a firm has in a destination, creating random measurement error, and causing the coefficient to be biased towards zero in the OLS regressions. By instrumenting import status using exogenous supply levels, the binary indicator becomes a continuous variable that is potentially better at proxying the size of a firm's supplier network. If the mechanism was indeed due to "shared 
TABLE 9 Firm and product characteristics

\section{(a) OLS-FE}

\begin{tabular}{|c|c|c|c|c|c|c|c|}
\hline & (1) & (2) & (3) & (4) & (5) & (6) & (7) \\
\hline \multirow[t]{2}{*}{$\ln (\text { imports })_{i, c, t-1}$} & $0.003 * * *$ & & & & & & \\
\hline & $(0.000)$ & & & & & & \\
\hline \multirow{2}{*}{$\ln (\text { no. of prod. })_{i, c, t-1}$} & & $0.037 * * *$ & & & & & \\
\hline & & $(0.003)$ & & & & & \\
\hline \multirow[t]{2}{*}{ import share $_{i, c, t-1}$} & & & $0.040 * * *$ & & & & \\
\hline & & & $(0.005)$ & & & & \\
\hline \multirow[t]{2}{*}{ share of diff. $\cdot i, c, t-1$} & & & & $0.035 * * *$ & & & \\
\hline & & & & $(0.003)$ & & & \\
\hline \multirow[t]{2}{*}{ share of quality $i_{i, c, t-1}$} & & & & & $0.033 * * *$ & & \\
\hline & & & & & $(0.004)$ & & \\
\hline \multirow[t]{2}{*}{ share of inputs $s_{i, c, t-1}$} & & & & & & $0.030 * * *$ & \\
\hline & & & & & & $(0.003)$ & \\
\hline \multirow[t]{2}{*}{ share of tech.i,c,t-1} & & & & & & & $0.035^{* * *}$ \\
\hline & & & & & & & $(0.004)$ \\
\hline No. of obs. & $4,895,216$ & $4,895,216$ & $4,895,216$ & $4,895,216$ & $4,895,216$ & $4,895,216$ & $4,895,216$ \\
\hline$R^{2}$ & 0.10 & 0.10 & 0.10 & 0.10 & 0.10 & 0.10 & 0.10 \\
\hline \multicolumn{8}{|l|}{ (b) IV } \\
\hline & (1) & (2) & (3) & (4) & (5) & (6) & (7) \\
\hline \multirow[t]{2}{*}{$\ln (\text { imports })_{i, c, t-1}$} & $0.010 * * *$ & & & & & & \\
\hline & $(0.001)$ & & & & & & \\
\hline \multirow[t]{2}{*}{$\ln (\text { no. of prod. })_{i, c, t-1}$} & & $0.111 * * *$ & & & & & \\
\hline & & $(0.015)$ & & & & & \\
\hline \multirow[t]{2}{*}{ import $_{\text {share }} e_{i, c, t-1}$} & & & $0.511^{* * *}$ & & & & \\
\hline & & & $(0.094)$ & & & & \\
\hline \multirow[t]{2}{*}{ share of diff. ${ }_{i, c, t-1}$} & & & & $0.218^{* * *}$ & & & \\
\hline & & & & $(0.032)$ & & & \\
\hline \multirow[t]{2}{*}{ share of quality $y_{i, c, t-1}$} & & & & & $0.337 * * *$ & & \\
\hline & & & & & $(0.047)$ & & \\
\hline \multirow[t]{2}{*}{ share of inputs $_{i, c, t-1}$} & & & & & & $0.143 * * *$ & \\
\hline & & & & & & $(0.017)$ & \\
\hline \multirow[t]{2}{*}{ share of tech.i,c,t-1} & & & & & & & $0.265^{* * *}$ \\
\hline & & & & & & & $(0.037)$ \\
\hline No. of obs. & $4,895,216$ & $4,895,216$ & $4,895,216$ & $4,895,216$ & $4,895,216$ & $4,895,216$ & $\begin{array}{l}4,895,216 \\
\text { (Continues) }\end{array}$ \\
\hline
\end{tabular}


TABLE 9 (Continued)

\section{(b) IV}

\begin{tabular}{lccccccc}
\hline & $(\mathbf{1})$ & $(\mathbf{2})$ & $(\mathbf{3})$ & $\mathbf{( 4 )}$ & $\mathbf{( 5 )}$ & $\mathbf{( 6 )}$ & (7) \\
$R^{2}$ (centred) & 0.09 & 0.09 & 0.07 & 0.06 & 0.04 & 0.08 & 0.06 \\
KP stat. & 63.84 & 43.63 & 33.72 & 25.21 & 42.28 & 69.34 & 38.60
\end{tabular}

Notes: The dependent variable is $F_{i, c, t}$ (export-market entry). The instrument is $\ln (E X)_{i, c, t-1}$. All regressions include $\ln I M_{i, c, t}$ and a region experience dummy which are omitted in the table. All regressions include firm-year and country-industry-year fixed effects. Standard errors clustered by firms $(6,716)$ and countries (191) in parentheses. See the main text for the definitions of the right-hand side variables. The critical value for Kleibergen-Paap (KP) statistic based on a 10 per cent maximal IV size is 16.38 . First-stage results are omitted for brevity. $* * *, * *$ and $*$ denote statistical significance at the 1,5 and 10 per cent levels, respectively.

fixed costs," then we would not expect to find larger IV coefficients. This comparison gives support to the "supplier network" hypothesis.

Section 5.1 shows that the effect of gravity-type variables such as GDP, distance, language proximity and development status is amplified when the firm has been importing from that country. This result might indicate that the shared component of fixed costs is larger in bigger, more proximate (both physically and linguistically) and richer countries. However, there is no reason why this would be the case. On the other hand, bigger and richer countries probably have larger and more fluid networks that are easier to access to once a supplier shows the way. Similarly, more proximate countries enable firms to have closer interactions with their suppliers, possibly enhancing the learning effect. The coefficient on RTAs reveals that trade agreements act as a substitute to having a supplier. This indicates that RTAs erode informational barriers, making suppliers irrelevant in accessing client networks. Even though this result can support both hypotheses, the finding that the effect does not depend on the magnitude of fixed trade costs strengthens the "supplier network" hypothesis. Section 5.1 also shows that the learning from importing effect is larger when (i) there are other exporters to that country in the firm's sector, and (ii) the destination has a Turkish immigrant community. These results reveal that the stock of market knowledge a firm has access to is valuable even when it has a supplier in the destination market.

Results in Section 5.2 also give support to the "supplier network" hypothesis as variables that proxy for the intensity of the supplier-buyer relationship (or the number of suppliers a firm has) should have no discernible effect on the shared component of fixed costs for exporting to and importing from a country. However, a story where the intensity of the relationship influences the chance of finding a client can explain why the number of imported products, and whether they are differentiated, matter. Overall, even though both mechanisms are potentially at play in generating the relationship between import experience and export-market entry, the results give more support to the "supplier network" hypothesis. If the shared fixed costs component was the leading mechanism, then the effect of previous export experience should have a similarly robust effect on import-market entry. This is not the case as shown in Appendix B.

\section{6 | CONCLUSION}

In this paper, following Chaney's (2014) conjecture of dynamic network formation where firms learn about potential clients using their existing clients in other destinations, I relied on an import 
experience proxy to analyse whether firms can use their existing suppliers to acquire their first clients in those countries based on an "extended-Chaney" information channel. Previous literature on the importance of sunk and fixed costs for the extensive margin of trade has largely ignored the supplier dimension and thus this is the first paper that analyses a firm's export-market entry probability by examining its other trading activity-importing.

Using a detailed data set of Turkish firms during 2003-08, I empirically tested whether the probability to start exporting depends on a firm's previous import experience with that country using an IV strategy. I used multiple high-dimensional fixed effects to shut down time-varying (i) firm characteristics such as productivity, and (ii) country-sector characteristics such as macro shocks. Using the remaining variation at the firm-country-year level, I instrumented previous importing with exogenous supply levels in the destination country. The IV results showed that having a supplier in the destination country increases the export-market entry probability by 5.5 percentage points (11 percentage points in the main IV specification). The general downward bias in OLS-FE coefficients was attributed to the potential measurement error of import status in proxying for the number of suppliers a firm has in a country. Several sensitivity analyses such as using different samples, experience measures and multiple instruments showed that results are robust.

The richness of the data set enabled me to dig deeper and explore heterogeneities. Using gravity-type interactions, I found that the "learning from supplier" effect does not exist when trading with low-income countries, but is more substantial when trading with larger and more proximate countries, as well as nations that speak a similar language to Turkish. The RTAs, on the other hand, did not have a positive effect on learning. I confirmed the findings of the literature on network effects by showing that the number of domestic peers as well as the size of the Turkish immigrant community in the destination country increase the probability of export-market entry, even when the firm has a supplier in that country. Moreover, I found that variables that proxy the strength of the firm's relationship with its supplier such as the share of imported products that are differentiated are positive predictors of export-market entry. A discussion of the results revealed that the mechanism behind the learning effect hints to the importance of accessing supplier networks to learn about potential clients.

This paper contributes to the literature by documenting the "market knowledge" effect, revealing that having a supplier in the destination country is important for a firm's export-market diversification. Whether it is learning about a country's culture, customs procedures, supply/demand functions or simply getting into a network of a country's buyers and sellers as in Chaney (2014), "market knowledge" is an important determinant of entering a market. These results suggest that large-scale trade policy implementations such as unilateral tariff liberalisation can have additional spillover effects by allowing firms to find suppliers in new markets that can lead to new clients in those markets. My findings also give credit to government subsidies for market research and international trade fairs where firms can find contacts to expand their geographical diversification. In fact, Turkey implemented a legislature to provide subsidies to attend international trade fairs in 2009 and to conduct (or purchase) market research for export-market entry for small and medium enterprises in 2011. Analysing the implications of these policy changes is left for future research.

\section{ACKNOWLEDGEMENTS}

I am grateful to Richard Baldwin, Nicolas Berman, Maarten Bosker, Chad Bown, Theresa Carpenter, Beata Javorcik, Stela Rubinova, and Yuan $\mathrm{Zi}$ for helpful comments at various stages of the development of this work. I especially thank Gönül Sarı and Gökalp Öz at the Istanbul branch of the Turkish Statistical Institute (TÜIK) for providing me with the data and patiently answering my 
queries. All the analyses for this paper have been conducted at the TÜIKK under a confidentiality agreement. The results and opinions shown here are the responsibility of the author and do not necessarily reflect the views of any agency of the Turkish government. All remaining errors are my own.

\section{ORCID}

Aksel Erbahar (D) https://orcid.org/0000-0001-7532-1456

\section{REFERENCES}

Abowd, J. M., \& Kramarz, F. (1999). Econometric analyses of linked employer-employee data. Labour Economics, 6(1), 53-74. https://doi.org/10.1016/S0927-5371(99)00003-2

Ahn, J., Khandelwal, A. K., \& Wei, S.-J. (2011). The role of intermediaries in facilitating trade. Journal of International Economics, 84(1), 73-85. https://doi.org/10.1016/j.jinteco.2010.12.003

Albornoz, F., Pardo, H. F. C., Corcos, G., \& Ornelas, E. (2012). Sequential exporting. Journal of International Economics, 88(1), 17-31. https://doi.org/10.1016/j.jinteco.2012.02.007

Allen, T. (2014). Information frictions in trade. Econometrica, 82(6), 2041-2083. https://doi.org/10.3982/ ECTA10984

Aristei, D., Castellani, D., \& Franco, C. (2013). Firms' exporting and importing activities: Is there a two-way relationship? Review of World Economics, 149(1), 55-84. https://doi.org/10.1007/s10290-012-0137-y

Arkolakis, C. (2010). Market penetration costs and the new consumer margin in international trade. Journal of Political Economy, 118(6), 1151-1199. https://doi.org/10.1086/657949

Baier, S. L., \& Bergstrand, J. H. (2007). Do free trade agreements actually increase members' international trade? Journal of International Economics, 71(1), 72-95. https://doi.org/10.1016/j.jinteco.2006.02.005

Baier, S. L., Bergstrand, J. H., \& Feng, M. (2014). Economic integration agreements and the margins of international trade. Journal of International Economics, 93(2), 339-350. https://doi.org/10.1016/j.jinteco.2014.03.005

Bastos, P., \& Silva, J. (2012). Networks, firms, and trade. Journal of International Economics, 87(2), 352-364. https://doi.org/10.1016/j.jinteco.2011.12.011

Berman, N., Berthou, A., \& Héricourt, J. (2015). Export dynamics and sales at home. Journal of International Economics, 96(2), 298-310. https://doi.org/10.1016/j.jinteco.2015.04.001

Bernard, A. B., Grazzi, M., \& Tomasi, C. (2015). Intermediaries in international trade: Products and destinations. Review of Economics and Statistics, 97(4), 916-920. https://doi.org/10.1162/REST_a_00495

Bernard, A. B., \& Jensen, J. B. (2004). Why some firms export. Review of Economics and Statistics, 86(2), 561569. https://doi.org/10.1162/003465304323031111

Bernard, A. B., Jensen, J. B., Redding, S. J., \& Schott, P. K. (2012). The empirics of firm heterogeneity and international trade. Annual Review of Economics, 4(1), 283-313. https://doi.org/10.1146/annurev-economics-080511110928

Cameron, A. C., Gelbach, J. B., \& Miller, D. L. (2011). Robust inference with multiway clustering. Journal of Business \& Economic Statistics, 29(2), 238-249. https://doi.org/10.1198/jbes.2010.07136

Carneiro, A., Guimarães, P., \& Portugal, P. (2012). Real wages and the business cycle: Accounting for worker, firm, and job title heterogeneity. American Economic Journal: Macroeconomics, 4(2), 133-152.

Casella, A., \& Rauch, J. E. (2002). Anonymous market and group ties in international trade. Journal of International Economics, 58(1), 19-47. https://doi.org/10.1016/S0022-1996(01)00160-X

Cassey, A. J., \& Schmeiser, K. N. (2013). The agglomeration of exporters by destination. The Annals of Regional Science, 51(2), 495-513. https://doi.org/10.1007/s00168-012-0538-9

Cavusgil, S. T., \& Zou, S. (1994). Marketing strategy-performance relationship: An investigation of the empirical link in export market ventures. The Journal of Marketing, 58(1), 1-21. https://doi.org/10.2307/1252247

Cebeci, T., \& Fernandes, A. M. (2015). Microdynamics of Turkey's export boom in the 2000s. The World Economy, 38(5), 825-855. https://doi.org/10.1111/twec.12183 
Chaney, T. (2008). Distorted gravity: The intensive and extensive margins of international trade. The American Economic Review, 98(4), 1707-1721. https://doi.org/10.1257/aer.98.4.1707

Chaney, T. (2014). The network structure of international trade. The American Economic Review, 104(10), 36003634. https://doi.org/10.1257/aer.104.11.3600

Combes, P.-P., Lafourcade, M., \& Mayer, T. (2005). The trade-creating effects of business and social networks: Evidence from France. Journal of International Economics, 66(1), 1-29. https://doi.org/10.1016/j.jinteco.2004.07.003

Das, S., Roberts, M. J., \& Tybout, J. R. (2007). Market entry costs, producer heterogeneity, and export dynamics. Econometrica, 75(3), 837-873. https://doi.org/10.1111/j.1468-0262.2007.00769.x

De Sousa, J. (2012). The currency union effect on trade is decreasing over time. Economics Letters, 117(3), 917920. https://doi.org/10.1016/j.econlet.2012.07.009

Defever, F., Heid, B., \& Larch, M. (2014). Spatial exporters. Journal of International Economics, 95(1), $145-156$.

Eaton, J., Kortum, S., \& Kramarz, F. (2011). An anatomy of international trade: Evidence from French firms. Econometrica, 79(5), 1453-1498.

Eslava, M., Tybout, J., Jinkins, D., Krizan, C., \& Eaton, J. (2015). A search and learning model of export dynamics.2015 Meeting Papers 1535, Society for Economic. Dynamics., Retrieved from: https://ideas.repec.org/ p/red/sed015/1535.htm.

Fernandes, A. P., \& Tang, H. (2014). Learning to export from neighbors. Journal of International Economics, 94(1), 67-84. https://doi.org/10.1016/j.jinteco.2014.06.003

Gullstrand, J. (2011). Firm and destination-specific export costs: The case of the Swedish food sector. Food Policy, 36(2), 204-213. https://doi.org/10.1016/j.foodpol.2010.11.017

Hatzichronoglou, T. (1997). Revision of the high-technology sector and product classification (OECD Science, Technology and Industry Working Papers, 1997/02). Retrieved from OECD website: https://www.oecd-ilibrary.org/docserve r/134337307632.pdf?expires $=1542140305 \& \mathrm{id}=\mathrm{id} \&$ accname $=$ guest $\&$ checksum $=0214993 \mathrm{DBA7108AC2D5CC6B4C}$ 4DC2669

Helpman, E., Melitz, M., \& Rubinstein, Y. (2008). Estimating trade ows: Trading partners and trading volumes. The Quarterly Journal of Economics, 123(2), 441-487. https://doi.org/10.1162/qjec.2008.123.2.441

Horrace, W. C., \& Oaxaca, R. L. (2006). Results on the bias and inconsistency of ordinary least squares for the linear probability model. Economics Letters, 90(3), 321-327. https://doi.org/10.1016/j.econlet.2005.08.024

Hummels, D., Jørgensen, R., Munch, J., \& Xiang, C. (2014). The wage effects of offshoring: Evidence from Danish matched worker-firm data. The American Economic Review, 104(6), 1597-1629. https://doi.org/10.1257/aer.104. 6.1597

Kasahara, H., \& Rodrigue, J. (2008). Does the use of imported intermediates increase productivity? Plant-level evidence. Journal of Development Economics, 87(1), 106-118. https://doi.org/10.1016/j.jdeveco.2007.12.008

Khandelwal, A. (2010). The long and short (of) quality ladders. Review of Economic Studies, 77(4), 1450-1476. https://doi.org/10.1111/j.1467-937X.2010.00602.x

Kneller, R., \& Pisu, M. (2011). Barriers to exporting: What are they and who do they matter to? The World Economy, 34(6), 893-930. https://doi.org/10.1111/j.1467-9701.2011.01357.x

Koenig, P. (2009). Agglomeration and the export decisions of French firms. Journal of Urban Economics, 66(3), 186-195. https://doi.org/10.1016/j.jue.2009.07.002

Krugman, P. (1980). Scale economies, product differentiation, and the pattern of trade. The American Economic Review, 70(5), 950-959.

Lall, S. (2000). The technological structure and performance of developing country manufactured exports, $1985-98$. Oxford Development Studies, 28(3), 337-369. https://doi.org/10.1080/713688318

Lancaster, T. (2000). The incidental parameter problem since 1948. Journal of Econometrics, 95(2), 391-413. https://doi.org/10.1016/S0304-4076(99)00044-5

Lederman, D., Olarreaga, M., \& Payton, L. (2010). Export promotion agencies: Do they work? Journal of Development Economics, 91(2), 257-265. https://doi.org/10.1016/j.jdeveco.2009.09.003

Leonidou, L. C. (2004). An analysis of the barriers hindering small business export development. Journal of Small Business Management, 42(3), 279-302. https://doi.org/10.1111/j.1540-627X.2004.00112.x

Martincus, C. V., \& Carballo, J. (2008). Is export promotion effective in developing countries? Firm-level evidence on the intensive and the extensive margins of exports. Journal of International Economics, 76(1), 89-106. https://doi.org/10.1016/j.jinteco.2008.05.002 
Martincus, C. V., \& Carballo, J. (2010). Entering new country and product markets: Does export promotion help? Review of World Economics, 146(3), 437-467. https://doi.org/10.1007/s10290-010-0062-x

Martincus, C. V., Estevadeordal, A., Gallo, A., \& Luna, J. (2010). Information barriers, export promotion institutions, and the extensive margin of trade. Review of World Economics, 146(1), 91-111. https://doi.org/10.1007/s10290-009-0043-0

Mayer, T., \& Zignago, S. (2011). Notes on CEPII's distances measures: The GeoDist database (CEPII Working Paper, 25). Retrieved from CEPII website: http://www.cepii.fr/PDF_PUB/wp/2011/wp2011-25.pdf

Melitz, M. J. (2003). The impact of trade on intra-industry reallocations and aggregate industry productivity. Econometrica, 71(6), 1695-1725. https://doi.org/10.1111/1468-0262.00467

Melitz, J., \& Toubal, F. (2014). Native language, spoken language, translation and trade Journal of International Economics, 93(2), 351-363. Retrieved from https://www.sciencedirect.com/science/article/pii/S0022199614000543

Morales, E., Sheu, G., \& Zahler, A. (2014). Gravity and extended gravity: Using moment inequalities to estimate a model of export entry (National Bureau of Economic Research Working Paper 19916). Retrieved from National Bureau of Economic Research website: https://www.nber.org/papers/w19916.pdf

Moxnes, A. (2010). Are sunk costs in exporting country specific? Canadian Journal of Economics/Revue canadienne d'économique, 43(2), 467-493. https://doi.org/10.1111/j.1540-5982.2010.01580.x

Muûls, M., \& Pisu, M. (2009). Imports and exports at the level of the firm: Evidence from Belgium. The World Economy, 32(5), 692-734. https://doi.org/10.1111/j.1467-9701.2009.01172.x

Neyman, J., \& Scott, E. L. (1948). Consistent estimates based on partially consistent observations. Econometrica: Journal of the Econometric Society, 16(1), 1-32. https://doi.org/10.2307/1914288

Özler, Ş., Taymaz, E., \& Yilmaz, K. (2009). History matters for the export decision: Plant-level evidence from Turkish manufacturing industry. World Development, 37(2), 479-488. https://doi.org/10.1111/twec.12020

Pierola, M. D., Fernandes, A. M., \& Farole, T. (2018). The role of imports for exporter performance in Peru. The World Economy, 41(2), 550-572. https://doi.org/10.1111/twec.12524

Pinho, J. C., \& Martins, L. (2010). Exporting barriers: Insights from Portuguese small-and medium-sized exporters and nonexporters. Journal of International Entrepreneurship, 8(3), 254-272. https://doi.org/10.1007/s10843-010-0046-x

Rauch, J. E. (1999). Networks versus markets in international trade. Journal of International Economics, 48(1), 735. https://doi.org/10.1016/S0022-1996(98)00009-9

Rauch, J. E., \& Trindade, V. (2002). Ethnic Chinese networks in international trade. Review of Economics and Statistics, 84(1), 116-130. https://doi.org/10.1162/003465302317331955

Roberts, M. J., \& Tybout, J. R. (1997). The decision to export in Colombia: An empirical model of entry with sunk costs. The American Economic Review, 87(4), 545-564.

Samiee, S., \& Walters, P. G. (2002). Export education: Perceptions of sporadic and regular exporting firms. International Marketing Review, 19(1), 80-97. https://doi.org/10.1108/02651330210419742

Schmeiser, K. N. (2012). Learning to export: Export growth and the destination decision of firms. Journal of International Economics, 87(1), 89-97. https://doi.org/10.1016/j.jinteco.2011.11.006

Tesfom, G., \& Lutz, C. (2006). A classification of export marketing problems of small and medium sized manufacturing firms in developing countries. International Journal of Emerging Markets, 1(3), 262-281. https://doi.org/ $10.1108 / 17468800610674480$

Turco, A. L., \& Maggioni, D. (2013). On the role of imports in enhancing manufacturing exports. The World Economy, 36(1), 93-120.

How to cite this article: Erbahar A. Market knowledge: Evidence from importers. World Econ. 2018;00:1-42. https://doi.org/10.1111/twec.12750 


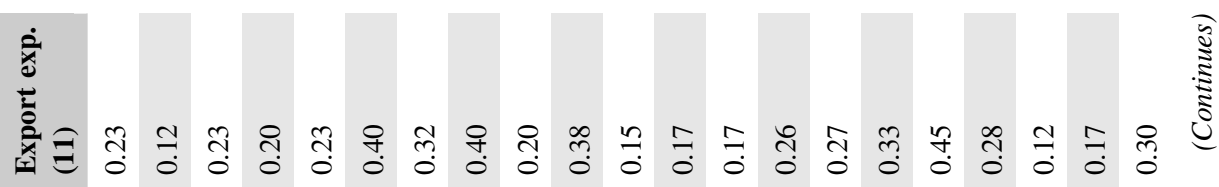
产

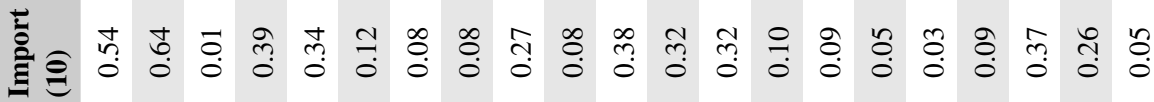

:

竞 密

音

E.

竞E 密

䒩 约-

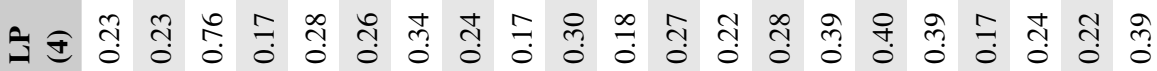

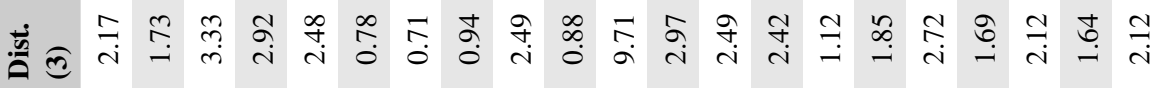

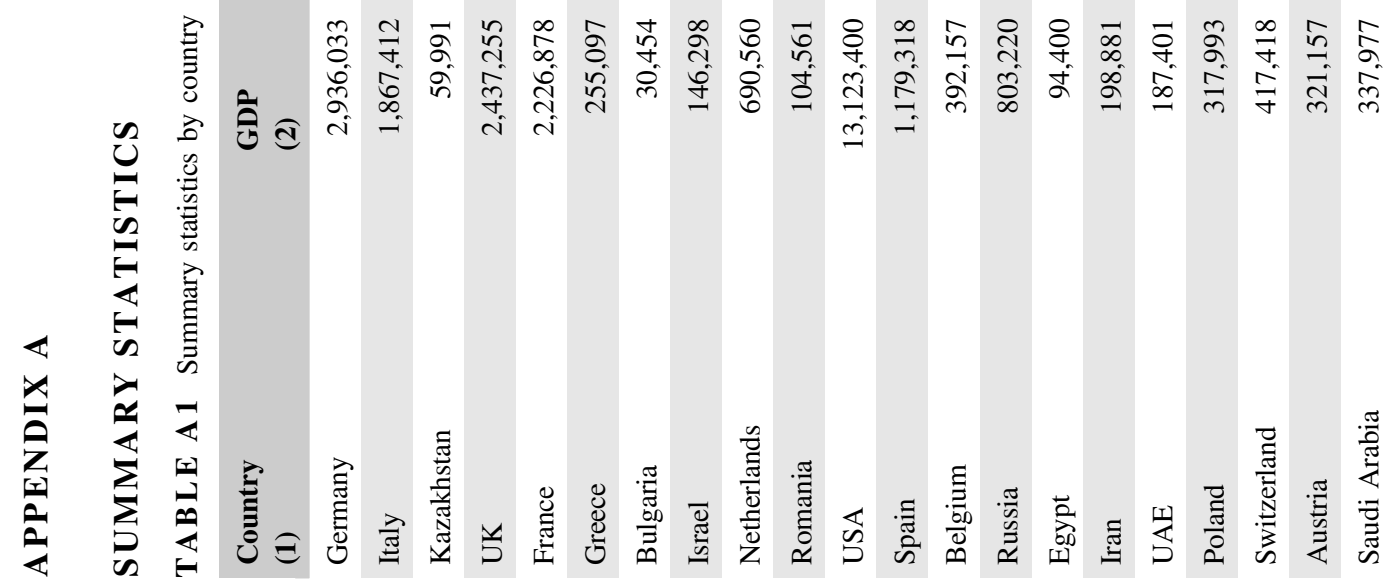




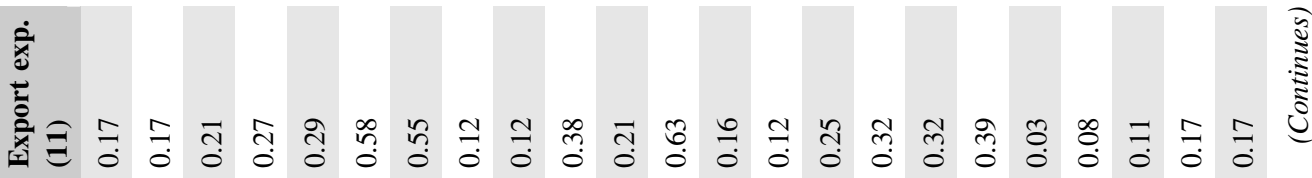
章 这

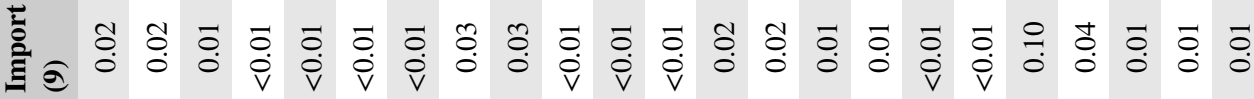
密

芒 这

竞

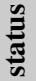

章

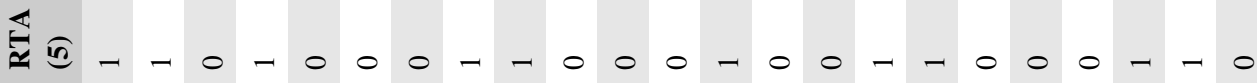

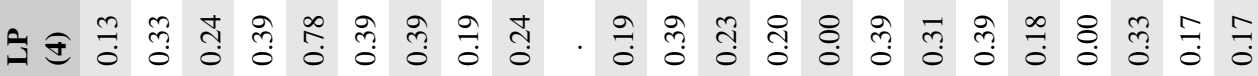

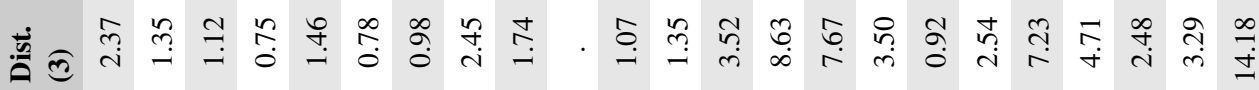

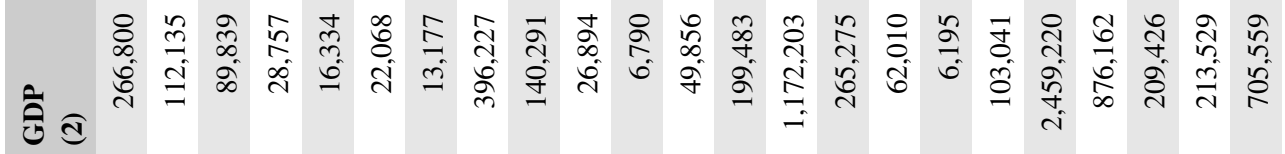

总

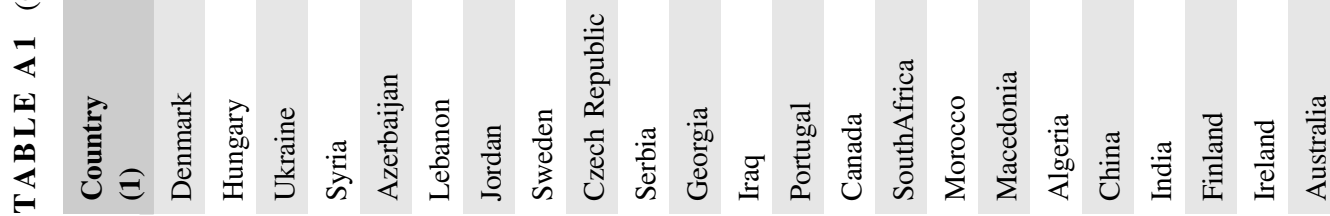


畜 竎苞

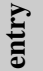

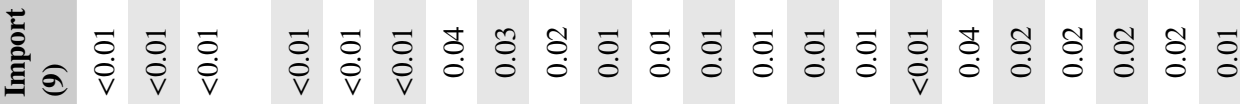
$\sum_{\bar{E}}^{\infty}$

苛 $\stackrel{3}{\Xi}$

晜 $\sum_{\bar{E}}^{\mathscr{E}}$

望

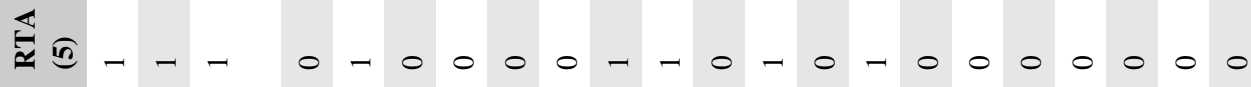

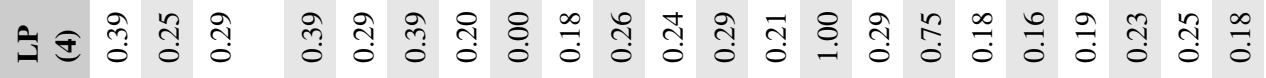
馬

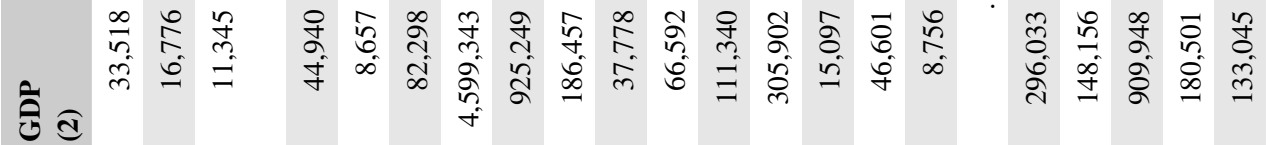


商

:

节苛

$\stackrel{\Xi}{\Xi}$

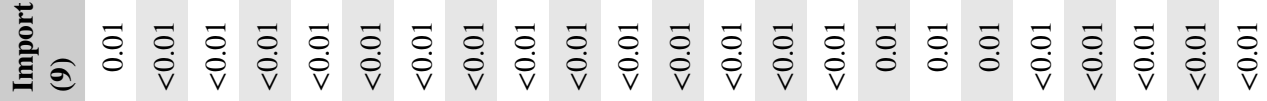

营

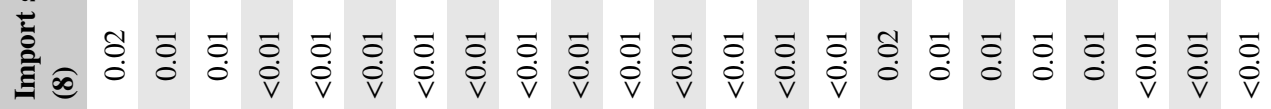

$\stackrel{E}{\Xi}$

离

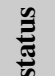

竞

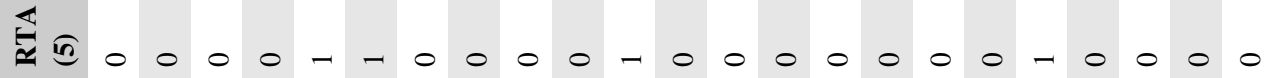

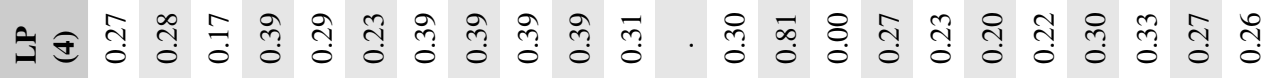

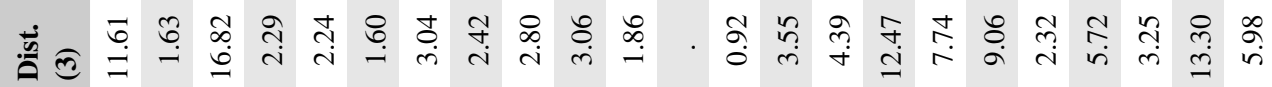

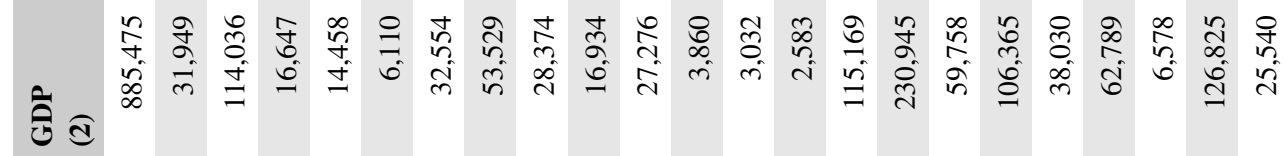

胥

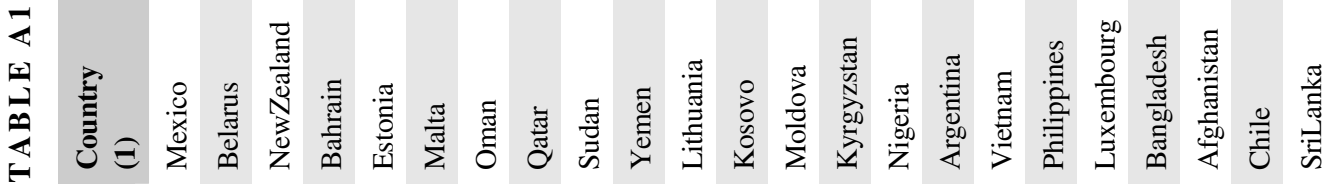


育畜

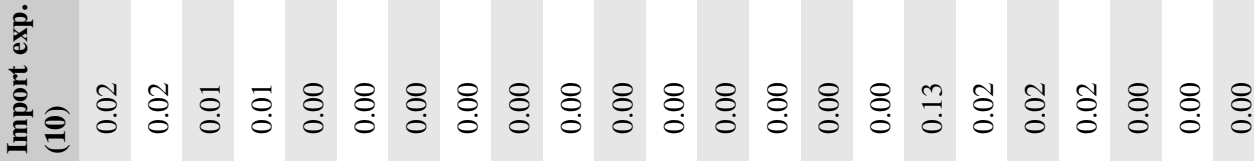

है

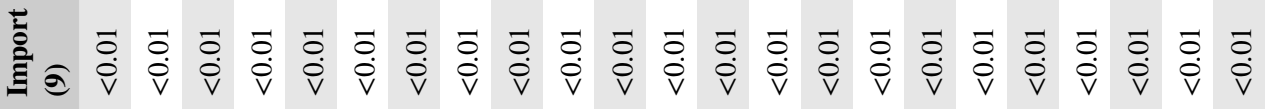

䓠

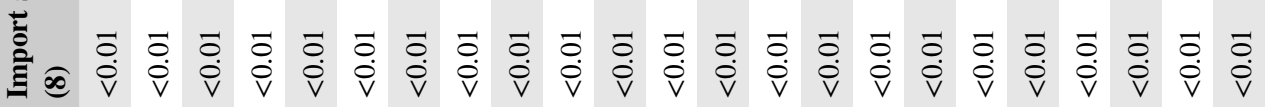

है

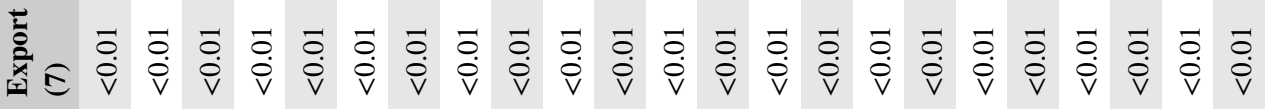

है

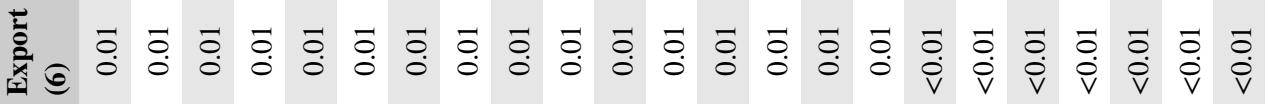

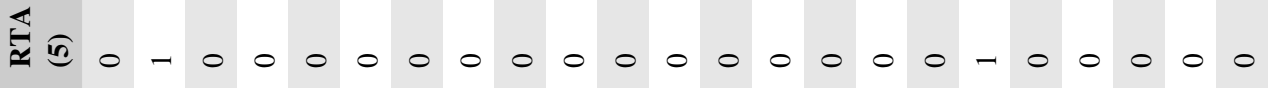

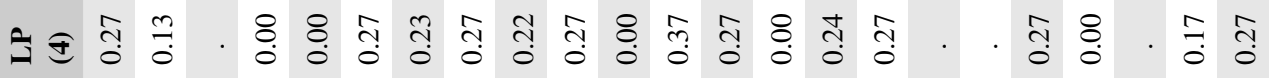

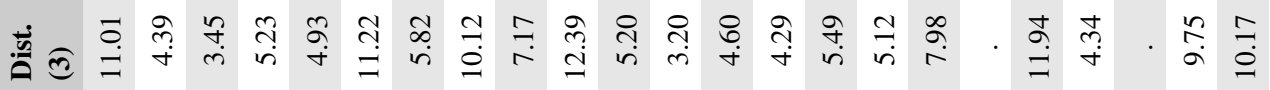

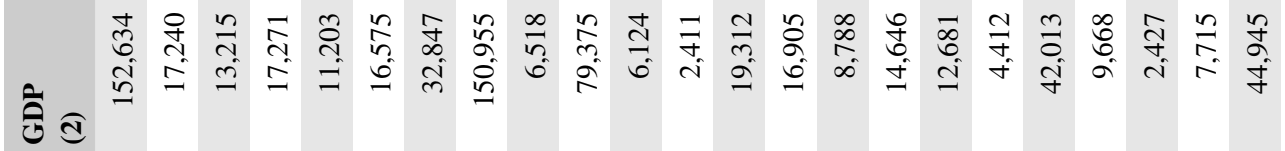


苟

安

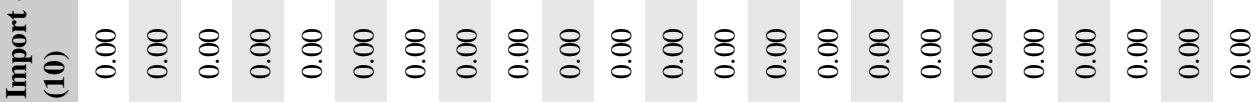

这

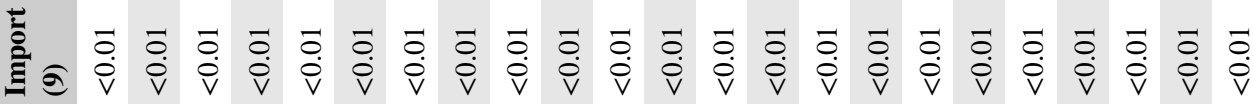

苞

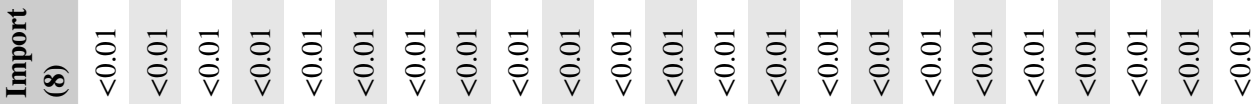

这

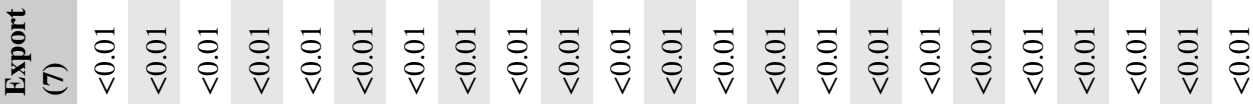

苞

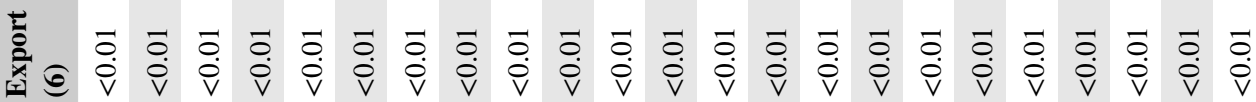

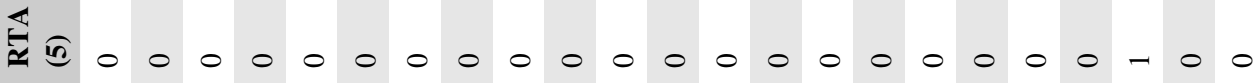

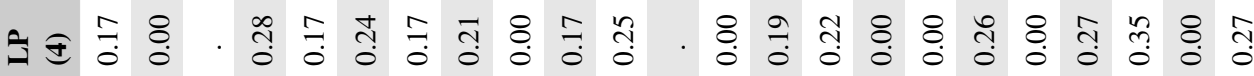
苛

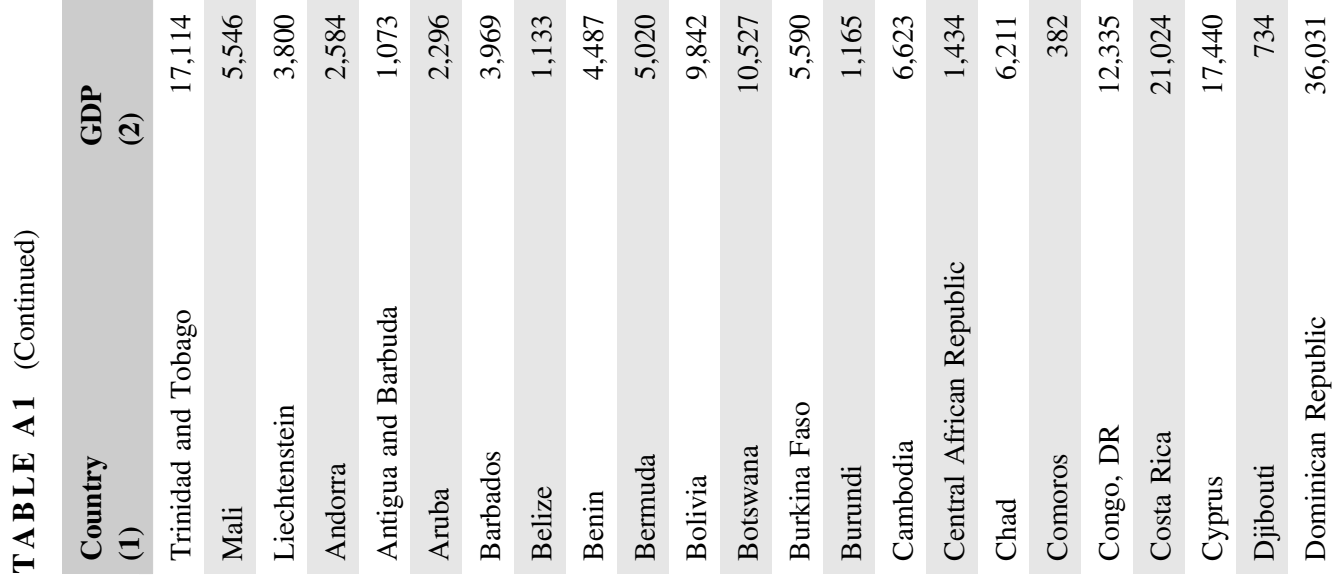


畜

항

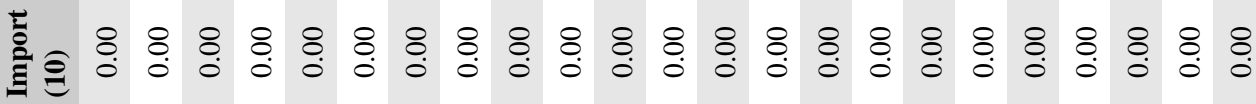

है

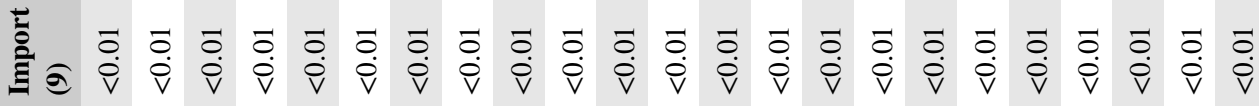

है

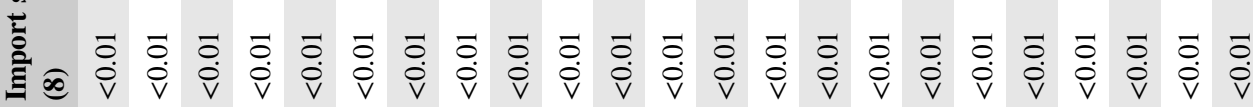

है

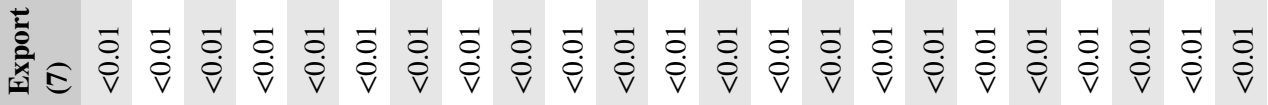

苞

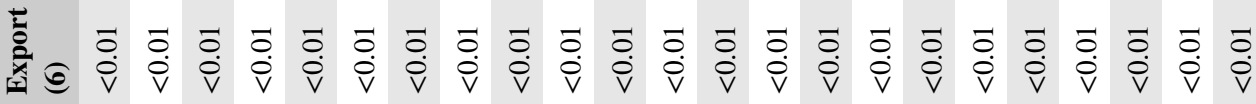

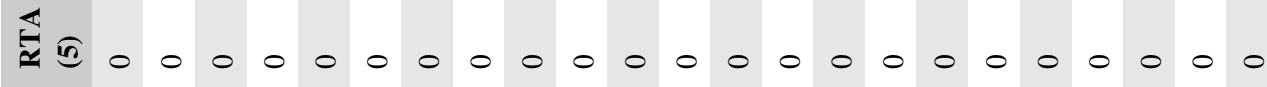
जิ

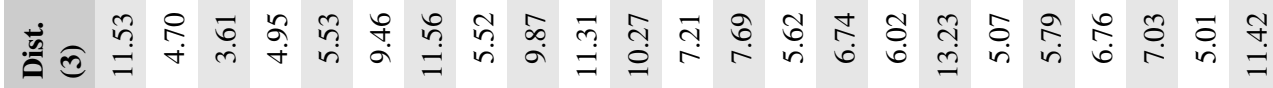
ธิธิธี

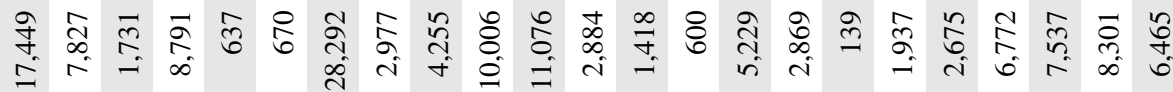




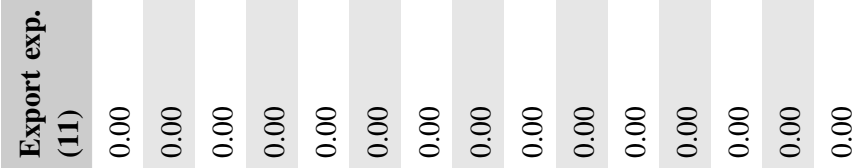

章

$\stackrel{\Xi}{\Xi}$

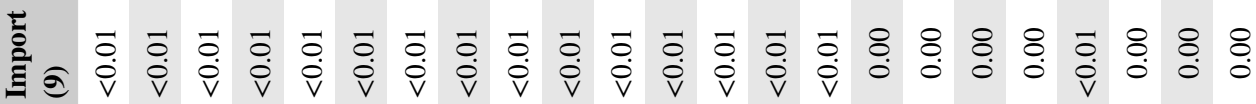

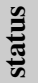

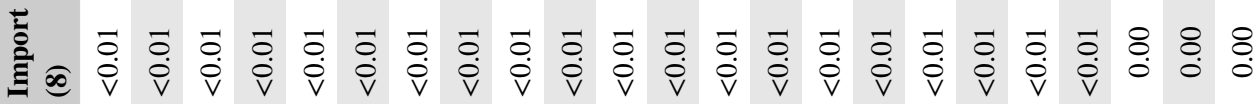

这

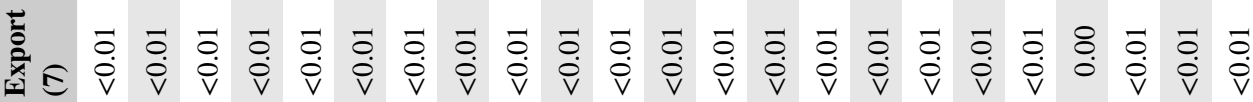

क्षे

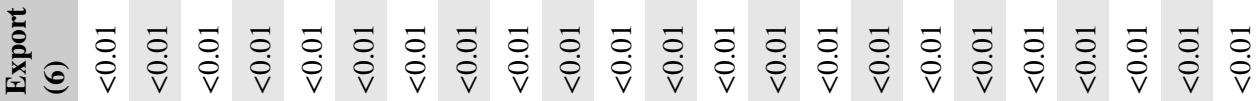

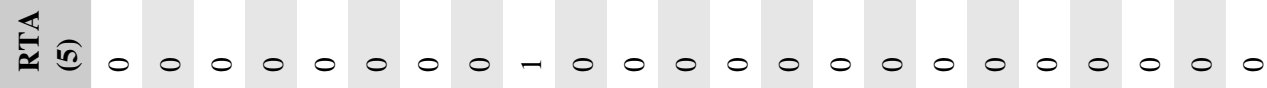
ज্] 㐫

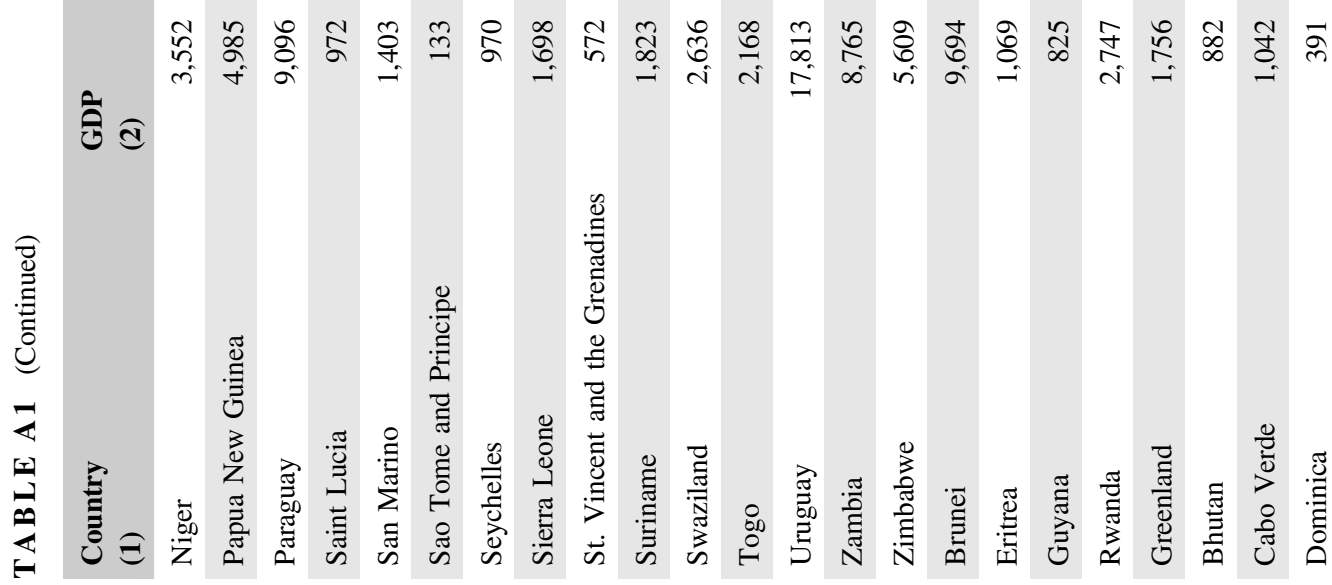




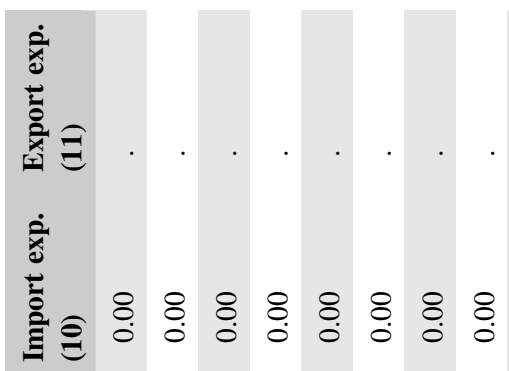

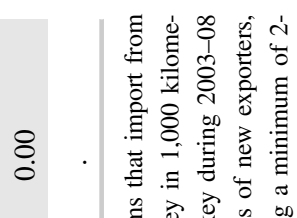

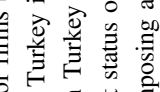
和

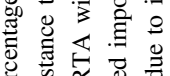

$\stackrel{\Xi}{0}$

苛

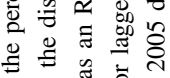

(ิ)

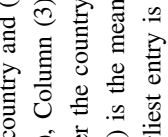

宽

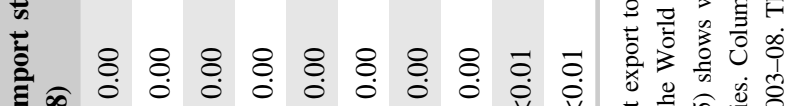

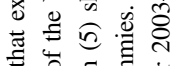

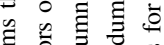

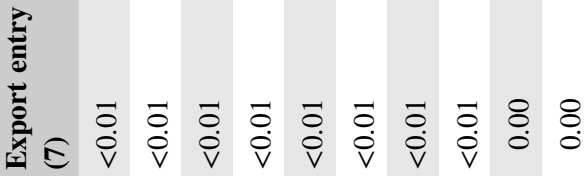

है

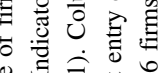

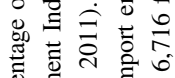

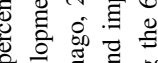

2.

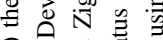

$\exists$ च

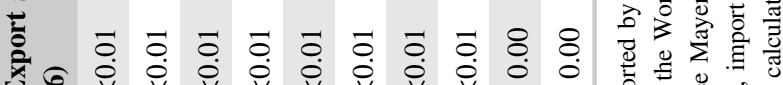

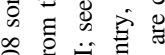

象芦言

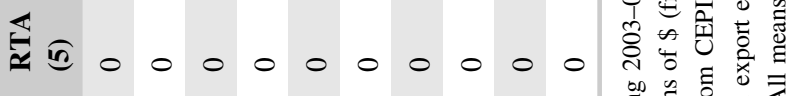

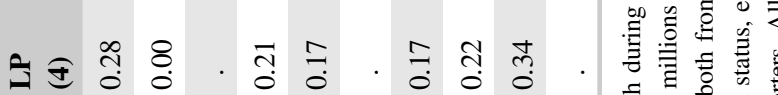

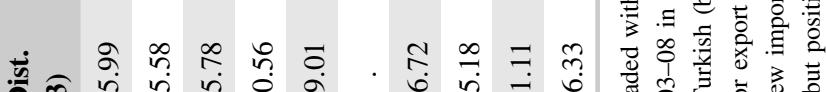

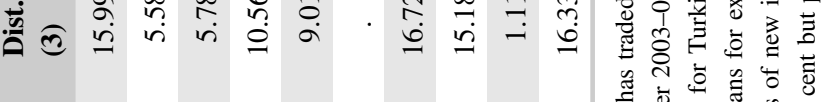

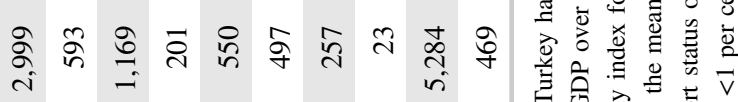

ปิธิช

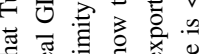

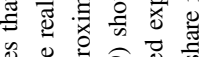

焉

氖

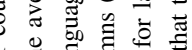

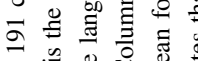

๑

毒宁

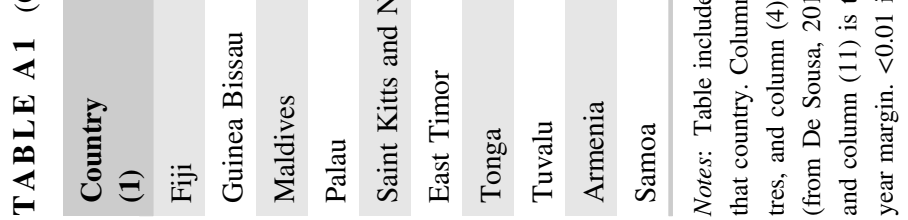


TABLE A2 Summary statistics for regressions

\begin{tabular}{|c|c|c|c|c|}
\hline Variable & Mean & $S D$ & Min. & Max. \\
\hline Export entry $_{i, c, t}$ & 0.008 & 0.089 & 0 & 1 \\
\hline Import status $_{i, c, t-1}$ & 0.018 & 0.134 & 0 & 1 \\
\hline Import entry $_{i, c, t-1}$ & 0.005 & 0.070 & 0 & 1 \\
\hline No. of import years ${ }_{i, c, t-1}$ & 0.059 & 0.392 & 0 & 5 \\
\hline Region experience $_{i, c, t-1}$ & 0.122 & 0.328 & 0 & 1 \\
\hline $\ln (I M)_{i, c, t}$ & 4.410 & 4.276 & 0 & 17.685 \\
\hline $\ln (E X)_{i, c, t-1}$ & 3.096 & 3.989 & 0 & 17.514 \\
\hline$G D P_{c, t-1}$ & $\$ 215 B$ & $\$ 991 B$ & $\$ 21.80 \mathrm{M}$ & $\$ 13,700 \mathrm{~B}$ \\
\hline $\ln (G D P)_{c, t-1}$ & 23.473 & 2.301 & 16.899 & 30.247 \\
\hline Distance $_{c}$ & 5,955 & 3,889 & 628 & 16,823 \\
\hline $\ln (\text { distance })_{c}$ & 8.430 & 0.786 & 6.443 & 9.731 \\
\hline Language proximity $_{c}$ & 0.230 & 0.153 & 0 & 1 \\
\hline $\mathrm{RTA}_{c, t-1}$ & 0.173 & 0.378 & 0 & 1 \\
\hline Low income ${ }_{c}$ & 0.170 & 0.376 & 0 & 1 \\
\hline Lower-middle income $_{c}$ & 0.237 & 0.425 & 0 & 1 \\
\hline Upper-middle income $_{c}$ & 0.280 & 0.449 & 0 & 1 \\
\hline High income $_{c}$ & 0.313 & 0.464 & 0 & 1 \\
\hline Ease of $\operatorname{trade}_{c}$ & 0.494 & 0.500 & 0 & 1 \\
\hline Peers $_{c, n, t-1}$ & 2.140 & 6.969 & 0 & 166 \\
\hline $\ln (\text { peers })_{c, n, t-1}$ & 0.525 & 0.871 & 0 & 5.118 \\
\hline Migrants $_{c}$ & 11,227 & 115,144 & 0 & $2.01 \mathrm{M}$ \\
\hline $\ln (\text { migrants })_{c}$ & 3.526 & 3.220 & 0 & 14.513 \\
\hline Value of imports ${ }_{i, c, t-1}$ & TL16,872 & TL1.13M & 0 & TL1,040M \\
\hline $\ln (\text { imports })_{i, c, t-1}$ & 0.200 & 1.503 & 0 & 20.764 \\
\hline No. of imported prod.i,c,t-1 & 0.048 & 0.636 & 0 & 141 \\
\hline $\ln (\text { no. of prod. })_{i, c, t-1}$ & 0.020 & 0.162 & 0 & 4.956 \\
\hline Import share $_{i, c, t-1}$ & 0.003 & 0.040 & 0 & 1 \\
\hline Share of differentiated ${ }_{i, c, t-1}$ & 0.011 & 0.102 & 0 & 1 \\
\hline Share of quality ${ }_{i, c, t-1}$ & 0.007 & 0.078 & 0 & 1 \\
\hline Share of inputs ${ }_{i, c, t-1}$ & 0.014 & 0.117 & 0 & 1 \\
\hline Share of tech. ${ }_{\cdot i, c, t-1}$ & 0.009 & 0.093 & 0 & 1 \\
\hline
\end{tabular}

Note: Summary statistics are based on the sample used for the main IV regressions in Table 5. 
TABLE A3 Number of importing years

\begin{tabular}{|c|c|c|c|c|c|c|}
\hline $\begin{array}{l}\text { No. of } \\
\text { importing } \\
\text { years: }\end{array}$ & $\beta_{1}$ (1 year) & $\beta_{2}$ (2 years) & $\beta_{3}$ (3 years) & $\beta_{4}$ (4 years) & & $\beta_{5}$ (5 years) \\
\hline & $0.014 * * *$ & $0.028 * * *$ & $0.037 * * *$ & $0.045^{* * *}$ & & $0.049 * * *$ \\
\hline & $(0.001)$ & $(0.003)$ & $(0.004)$ & $(0.005)$ & & $(0.005)$ \\
\hline$H_{0}: \beta_{i}=\beta_{i+1}$ & & 0.00 & 0.00 & 0.04 & 0.25 & \\
\hline
\end{tabular}

Notes: The dependent variable is $F_{i, c, t}$ (export-market entry) and the independent variables are number of importing year dummies. The omitted category is "no importing experience." The explanatory variables also include $\ln I M_{i, c, t}$, region experience dummy, and firm-year and country-industry-year fixed effects. Number of observations is 4,895,216 and $R^{2}$ is 0.10 . Standard errors in parentheses are clustered multiway by firms $(6,716)$ and countries $(191)$. ***,** and * denote statistical significance at the 1,5 and 10 per cent levels, respectively. The last row tests the equality of coefficients, and the column entries show Prob $>F$.

\section{APPENDIX B}

\section{TURNING THE TABLES: SEARCHING FOR SUPPLIERS THROUGH CLIENTS?}

Here, I empirically examine whether firms can also learn about new suppliers using their existing network of clients in a country. Results below, in a sense "turn the tables," and replicate the main analysis by changing the dependent variable to import-market entry and define analogous explanatory export experience variables.

Table B1 shows that the effect of previous exporting on import-market entry is very similar to the results in Table 4, where I examined the effect of previous importing on export-market entry. A comparison between the two tables reveals that the learning effect seems to work in both ways. In fact, panel (a) column (3) shows that a positive export status in $t-1$ increases the probability of import-market entry by 3.2 percentage points, equivalent to the effect found in Table 4 panel (a) column (2).

In Table B2 I instrument having a client in the destination country with that country's exogenous import demand level, created analogously as in Section 2.3. Again, similar to the findings in Table 5, the coefficients rise in magnitude. However, panel (b) shows that using multiple instruments causes the export experience variable to lose its statistical significance. Moreover, the Hansen $p$-values in Columns (4) and (6) reveal that the exogeneity of the instruments is rejected at the 5 per cent level. ${ }^{45}$ Hence, the results found for the effect of export experience on import entry are not conclusive and thus I relegate the analysis to the Appendix. More research is needed to understand firms' search for new suppliers as the model provided by Chaney (2014) does not give a clear prediction for this channel.

\footnotetext{
${ }^{45}$ I exclude EU countries in order to have variation in the tariff instrument.
} 
T A B LE B 1 Effect of exporting on import-market entry - OLS-FE

\begin{tabular}{llcc}
$\boldsymbol{F}_{\boldsymbol{i}, \boldsymbol{c}, \boldsymbol{t} \mathbf{1}}$ & $\mathbf{( 1 )}$ & $\mathbf{( 2 )}$ & $\mathbf{( 3 )}$ \\
\hline Export status & $0.032 * * *$ & $0.032 * * *$ & $0.013 * * *$ \\
& $(0.003)$ & $(0.003)$ & $(0.001)$ \\
\hline No. of obs. & $4,908,902$ & $4,908,902$ & $4,908,902$ \\
$R^{2}$ & 0.05 & 0.11 & 0.58 \\
\hline Export entry & $0.023^{* * *}$ & $0.022^{* * *}$ & $0.005 * * *$ \\
& $(0.002)$ & $(0.002)$ & $(0.001)$ \\
\hline No. of obs. & $3,669,128$ & $3,669,128$ & $3,669,128$ \\
$R^{2}$ & 0.04 & 0.11 & 0.65 \\
\hline Export years & $0.011 * * *$ & $0.011 * * *$ & $0.021 * * *$ \\
& $(0.001)$ & $(0.001)$ & $(0.002)$ \\
\hline No. of obs. & $4,908,902$ & $4,908,902$ & $4,908,902$ \\
\hline$R^{2}$ & 0.05 & 0.11 & 0.58 \\
\hline$F E$ & $\mathrm{FY}, \mathrm{CY}$ & $\mathrm{FY}, \mathrm{CNY}$ & $\mathrm{FY}, \mathrm{CY}, \mathrm{FC}$ \\
\hline
\end{tabular}

Notes: The dependent variable is $S_{i, c, t}$ (import-market entry). Each coefficient represents an estimate from a separate regression. All regressions include $\ln E X_{i, c, t}$ (omitted in the table for brevity). Fixed effects $(F E$ ) definitions are as follows: FY (firm-year), CY (country-year), CNY (country-industry-year) and FC (firm-country). Standard errors clustered multiway by firms $(6,716)$ and countries (191) in parentheses. $* * *, * *$ and $*$ denote statistical significance at the 1,5 and 10 per cent levels, respectively.

T A B LE B 2 Effect of exporting on import-market entry - IV

\begin{tabular}{|c|c|c|c|c|c|c|}
\hline & \multicolumn{3}{|c|}{ (a) Single IV } & \multicolumn{3}{|c|}{ (b) Multiple IVs } \\
\hline & (1) & (2) & (3) & (4) & (5) & (6) \\
\hline & Status & Entry & Years & Status & Entry & Years \\
\hline \multirow{2}{*}{$F_{i, c, t-1}$} & $0.299 * * *$ & $0.827 * * *$ & $0.092 * * *$ & 0.006 & 0.018 & 0.002 \\
\hline & $(0.039)$ & $(0.111)$ & $(0.012)$ & $(0.032)$ & $(0.130)$ & $(0.009)$ \\
\hline \multirow[t]{2}{*}{$\ln (E X)_{i, c, t}$} & $0.001 * * *$ & $0.001 * * *$ & $0.001 * * *$ & $0.001 * * *$ & $0.001 * * *$ & $0.001 * * *$ \\
\hline & $(0.000)$ & $(0.000)$ & $(0.000)$ & $(0.000)$ & $(0.000)$ & $(0.000)$ \\
\hline \multirow[t]{2}{*}{$\ln (T T A R)_{i, c, t}$} & & & & 0.005 & 0.001 & 0.005 \\
\hline & & & & $(0.013)$ & $(0.012)$ & $(0.013)$ \\
\hline No. of obs. & 4,908,902 & $3,669,128$ & $4,908,902$ & $3,102,216$ & $2,332,854$ & $3,102,216$ \\
\hline$R^{2}$ (centred) & -0.07 & -0.55 & -0.01 & 0.12 & 0.12 & 0.12 \\
\hline KP stat. & 59.51 & 66.91 & 62.68 & 19.24 & 20.86 & 19.11 \\
\hline Hansen $p$-value & . & . & . & 0.04 & 0.32 & 0.04 \\
\hline
\end{tabular}

Notes: The dependent variable is $S_{i, c, t}$ (import-market entry). Columns differ in the variable used for $F_{i, c, t-1}$. All regressions include firm-year and country-industry-year fixed effects. Standard errors clustered multiway by firms $(6,716$ in columns (1-3), 5,506 in columns (4-6)) and countries (191 in columns (1-3), 148 in columns (4-6)) in parentheses. In Columns (4-6), EU countries are dropped in order to have meaningful variation in the tariff instrument. All logs and instruments are calculated by adding 1 to the relevant value before taking the log to avoid zeros. For columns (1-3) (4-6), the critical value for Kleibergen-Paap (KP) statistic based on a 10 per cent maximal IV size is 16.38 (19.93). First-stage results are omitted for brevity. ***, ** and * denote statistical significance at the 1,5 and 10 per cent levels, respectively. 